IZA DP No. 6952

Policy Responses to Fiscal Restraints:

A Difference-in-Discontinuities Design

Veronica Grembi

Tommaso Nannicini

Ugo Troiano

October 2012 


\title{
Policy Responses to Fiscal Restraints: A Difference-in-Discontinuities Design
}

\author{
Veronica Grembi \\ Catholic University of Milan
}

Tommaso Nannicini

Bocconi University, IGIER and IZA

Ugo Troiano

Harvard University

\section{Discussion Paper No. 6952 \\ October 2012}

\author{
IZA \\ P.O. Box 7240 \\ 53072 Bonn \\ Germany \\ Phone: +49-228-3894-0 \\ Fax: +49-228-3894-180 \\ E-mail: iza@iza.org
}

Any opinions expressed here are those of the author(s) and not those of IZA. Research published in this series may include views on policy, but the institute itself takes no institutional policy positions. The IZA research network is committed to the IZA Guiding Principles of Research Integrity.

The Institute for the Study of Labor (IZA) in Bonn is a local and virtual international research center and a place of communication between science, politics and business. IZA is an independent nonprofit organization supported by Deutsche Post Foundation. The center is associated with the University of Bonn and offers a stimulating research environment through its international network, workshops and conferences, data service, project support, research visits and doctoral program. IZA engages in (i) original and internationally competitive research in all fields of labor economics, (ii) development of policy concepts, and (iii) dissemination of research results and concepts to the interested public.

IZA Discussion Papers often represent preliminary work and are circulated to encourage discussion. Citation of such a paper should account for its provisional character. A revised version may be available directly from the author. 


\title{
ABSTRACT
}

\section{Policy Responses to Fiscal Restraints: A Difference-in-Discontinuities Design}

\begin{abstract}
We evaluate the effect of relaxing fiscal rules on policy outcomes applying a quasiexperimental research design. In 1999, the Italian central government introduced fiscal rules aimed at imposing fiscal discipline on municipal governments, and in 2001 the rules were relaxed for municipalities below 5,000 inhabitants. This institutional change allows us to implement a "difference-in-discontinuities" design by combining the before/after with the discontinuous policy variation. Our estimates show that relaxing fiscal rules triggers a substantial deficit bias, captured by a shift from a balanced budget to a deficit that amounts to 2 percent of the total budget. The deficit comes primarily from reduced revenues as unconstrained municipalities have lower real estate and income tax rates. Finally, we investigate the heterogeneity in policy responses across municipalities to provide new evidence about the costs and benefits of restricting fiscal policy. The impact is larger if the mayor can run for reelection, the number of political parties seated in the city council is higher, voters are older, the performance of the mayor in providing public good is lower, and cities are characterized by historical deficit, consistently with models on the political economy of fiscal adjustment.
\end{abstract}

JEL Classification: $\quad \mathrm{C} 21, \mathrm{C} 23, \mathrm{H} 62, \mathrm{H} 72, \mathrm{H} 77$

Keywords: fiscal rules, local government finance, difference-in-discontinuities

Corresponding author:

Ugo Troiano

Harvard University

Department of Economics

Littauer Center

1805 Cambridge Street

Cambridge, MA 02138

USA

E-mail: troiano@fas.harvard.edu

\footnotetext{
* A previous version of this paper circulated under the title "Do Fiscal Rules Matter? A Difference-inDiscontinuities Design." We thank Alberto Alesina, Robert Barro, Raj Chetty, and Larry Katz for detailed suggestions. We thank Daron Acemoglu, Philippe Aghion, Roland Benabou, Marianne Bertrand, David Cutler, John Friedman, Ed Glaeser, Nate Hendren, Brian Knight, David Laibson, Mandy Pallais, Roberto Perotti, Per Pettersson-Lidbom, László Sándor, Frank Schilbach, Guido Tabellini, and seminar participants at Bank of Italy, Bologna University, Boston University, CELS 2012 Northwestern University, CEPR Public Policy Symposium, Catholic University of Milan, CIFAR, CeSiFo, CSEF Naples, Erasmus University Rotterdam, Harvard Development, Labor and Macro Lunch, IGIER-Bocconi, NBER Summer Institute, and USI Lugano for insightful comments. Errors are ours and follow a random walk. Financial support is gratefully acknowledged from Catholic University of Milan for Grembi; the ERC (Grant No. 230088) and Bocconi for Nannicini; Harvard Department of Economics and Multidisciplinary Program in Inequality \& Social Policy, Bank of Italy, and EIEF for Troiano. We also thank Giancarlo Verde, Carmine La Vita, Daniela De Marte (Italian Ministry of the Interior), and Salvatore Parlato (Ifel-ANCI) for help with data collection.
} 


\section{Introduction}

Can fiscal restraints imposed on local governments create incentives for reducing the accumulation of debt? The need for fiscal adjustment in the aftermath of the Great Recession has revived interest in fiscal rules aimed at disciplining the discretionary power of policy makers. Despite extensive research, the impact of fiscal restraints on debt accumulation and their effectiveness in reducing politically motivated deficit remain highly debated. ${ }^{1}$ As the authors in the literature have acknowledged - see, for example, the discussion in Poterba (1996) or Alesina and Perotti (1996) - the search for a definitive conclusion is hampered by the potentially endogenous decision of whether to adopt fiscal rules or not. ${ }^{2}$

In this paper, we study the effect of relaxing fiscal restraints at the local government level. We first show quasi-experimentally that fiscal rules do matter for restraining the accumulation of debt and the fiscal adjustment is concentrated on revenues. We then give evidence suggesting that the adjustment is driven by cities with more political distortions. We overcome previous data and identification limitations by using a novel identification design.

Our setting is Italy, where the central government set a target on deficit reduction for all municipal governments in 1999 - the so called "Domestic Stability Pact," DSP henceforthand relaxed it for municipalities below 5,000 inhabitants in 2001. This policy change allows us to combine two sources of variation, before/after 2001 and just below/above 5,000 inhabitants, and implement what we call a "difference-in-discontinuities" (or "diff-in-disc") design. It is important to note that a (standard) cross-sectional Regression Discontinuity (RD) design would not allow us to identify the effect of relaxing fiscal rules in this setting. The fact that there is another policy, started in the 1960s and still in place, according to which mayors of cities above 5,000 residents receive a higher salary, implies that analyzing the discontinuity at 5,000 residents in any given year would not identify the effect of the DSP.

The intuition for our identification strategy is simple. The diff-in-disc estimator takes the difference between the cross-sectional discontinuity at 5,000 after 2001 (when both fiscal rules

\footnotetext{
${ }^{1}$ As indicated by Drazen (2002) in a review article: "A key question (perhaps the key question) about fiscal rules is whether they have the effect of slowing the growth of deficits."

${ }^{2}$ Furthermore, there has been limited investigation on fiscal rules at the local government level, where forms of "hidden" public debt can grow and raise fears about the overall financial sustainability of a country. For a review of the current state of the literature, see Glaeser (2012). On the one hand, fiscal rules imposed on local governments might be particularly effective because a higher level of government can credibly enforce punishment. On the other hand, local governments usually have limited autonomy in adjusting fiscal policy.
} 
and the mayor's salary show a jump) and the cross-sectional discontinuity at 5,000 before 2001 (when only the mayor's salary shows a jump). We derive precise identifying assumptions under which this estimator can identify different types of average treatment effects in the neighborhood of the population threshold. The assumptions are milder than those required for a cross-sectional RD design or for a difference-in-differences strategy. We can therefore improve upon the previous literature in terms of internal validity by identifying the causal effect of relaxing fiscal restraints on policy outcomes. ${ }^{3}$

The main rule established by the DSP imposed a gradual reduction of the "fiscal gap," defined as the municipal deficit net of transfers and debt service. The rationale for the exemption of municipalities with less than 5,000 inhabitants in 2001 was to avoid burdening very small towns with onerous requirements, as they may be disadvantaged by economies of scale in managing the municipal government. The penalties put in place for not complying with the DSP included a cut in the annual transfers from the central government, a ban on new hires, and a cut on reimbursement and non-absenteeism bonuses. This means that, in the regulatory environment we study, there is a central authority that can collect standardized public accounts and enforce punishment for non-compliers.

A number of studies have argued that there are several reasons why fiscal rules might be ineffective in restraining fiscal policy (see, for example, the review by Alesina and Perotti, 1996, and Wyplosz, 2012). ${ }^{4}$ Additionally, the approval of the DSP was accompanied by widespread skepticism about its effectiveness, as Italy usually ranks last among OECD countries in ratings of law enforcement and government effectiveness (e.g., see Kaufmann, Kraay, and Mastruzzi, 2010). In light of these arguments, our results suggest that the lessons we draw from Italian municipalities on the effectiveness of fiscal rules may extend to other regulatory environments where the fiscal authority setting the rules faces critical ex-ante commitment problems.

\footnotetext{
${ }^{3}$ See Section 4 for a formal discussion of identification, estimation, and diagnostics in diff-in-disc.

${ }^{4}$ First, the fact that subnational policy makers have limited discretion in changing fiscal policy is the central reason for which fiscal rules on local governments might not work. Second, most fiscal rules, including those we are analyzing, are not embedded in the constitution. This implies that fiscal responsibility laws can be frequently changed and revised, and they might suffer from the same time inconsistency problem that characterizes fiscal policy. Additionally, Alesina and Perotti (1996) argue that lax enforcement is one of the reasons why fiscal rules might not work. This concern, however, is more relevant at the national level, since at the local level the central government can be a credible enforcement authority. Finally, rules usually target only some parts of the budget and this offers opportunities for policy makers to sidestep the rules by complying with them without changing the overall fiscal discipline - see Milesi-Ferretti (2003).
} 
We divide our empirical analysis into three parts. First, we analyze the impacts of relaxing fiscal restraints on the deficit, which is the main policy variable of interest, and on the fiscal gap, which is the main target of the law. We find that relaxing fiscal rules translates into a larger fiscal gap of about 40 to 60 percent over the course of the following 4 years. This large effect on the main target of the DSP has real consequences for policy outcomes, as unconstrained municipalities increase their deficit by 20 Euros per capita (2 percent of the total budget). The fact that we find an effect not only for the target of the DSP, but also for the main policy variable of interest not targeted by the law (that is, debt accumulation) alleviates concerns arising from the possibility of creative accounting.

In the second part of our empirical analysis, we study the composition of the fiscal adjustment, by analyzing municipal financial reports and administrative data on municipal tax rates, which are set by the local policy makers. We find that unconstrained municipalities have statistically similar expenditure levels with respect to constrained municipalities, but have lower tax revenues. This difference can be partially explained by the additional finding that municipalities for which fiscal rules are relaxed set lower tax rates. The main tax rates decided by Italian cities are a real estate tax rate on home property (Imposta Comunale sugli Immobili, ICI), which provides almost 50 percent of municipal tax revenues, and a surcharge on the personal income tax (Imposta sul Reddito delle Persone Fisiche, IRPEF), which amounts to about 10 percent of municipal tax revenues. Cities for which fiscal rules are relaxed have both a lower real estate tax rate (by about 14 percent) and a lower income tax surcharge (by about 30 percent) after the policy shift.

Finally, in the third part of the analysis, we exploit the fact that our setup - that is, an exogenously imposed fiscal destabilization - can provide new evidence on when fiscal restraints matter the most. On the one hand, the optimal tax smoothing theory would suggest that countercyclical deficits can increase welfare by equalizing the distortionary cost of taxation across booms and recessions. ${ }^{5}$ On the other hand, a persistent deficit bias might be the suboptimal result of the interplay between rational politicians, voters, and interest groups. Our empirical findings suggest that political factors play a first-order role in fiscal adjustments.

We first compare municipalities where only two political parties are represented in the local legislative assembly (about half of the sample) versus municipalities with more parties.

\footnotetext{
${ }^{5}$ See Barro (1974), Barro (1979), and Lucas and Stokey (1983).
} 
Our results show that relaxing fiscal rules increases the deficit only if more than two parties are seated in the assembly, which must approve the budget proposed by the mayor. This finding is consistent with models that explain deficit as the result of political fragmentation and of dynamic common pool (see Persson and Tabellini, 2000), and also with the crosscountry evidence that coalition governments are associated with higher deficits (see Roubini and Sachs, 1989; Kontopoulos and Perotti, 1999).

We then study if the relaxation of fiscal rules is affected by whether the mayor faces a binding term limit or not. We find that the increase in deficit bias arises only for mayors who can be reelected. This result is consistent with models linking deficit to reelection incentives (see Aghion and Bolton, 1990) or to politicians' pandering to voters (see Maskin and Tirole, 2004). We also show that cities that increase the municipal deficit after the relaxation of fiscal rules have an older population. These results are consistent with the model of Song, Storesletten, and Zilibotti (2012), according to which young citizens have a disciplining role for fiscal policy because they internalize the future costs of present fiscal instability.

Furthermore, we relate our findings to models that formalize the welfare costs and benefits of fiscal restraints. First, we show that the increase in deficit bias arises only for mayors that systematically underprovide the public good promised to the voters in the provisional budget. This evidence can be interpreted as consistent with the model of Besley (2007), to the extent to which politicians who consistently overpromise public goods are those who care more about reelection rather than social welfare. Finally, we relate our findings to the empirical prediction of Battaglini and Coate (2008). These authors predict that the welfare costs of restraining fiscal policy are limited when deficit is a historically persistent phenomenon, rather than a cyclical one. We show that our results are not driven by cities with cyclical deficit, and - if anything - the opposite is true, even if data limitations do not allow us to draw a definitive conclusion.

Our results survive a large number of robustness checks. Among those, we use the introduction of the DSP for all municipalities in 1999 as a falsification test to show that our results are not driven by cities just below and above 5,000 responding differently to the same set of fiscal rules. This test suggests that better paid (and, hence, better selected) mayors do not react differently to the relaxation of the DSP compared to mayors with a lower salary, and it is reassuring for the external validity of our results. Additionally, we repeat our falsifica- 
tion exercise interacting our treatment variable with the heterogeneity dimensions discussed above, in order to show that the law did not bind differently across those subsamples.

The paper proceeds as follows. Section 2 summarizes the relevant literature. Section 3 describes the Italian institutional framework. Section 4 lays out our identification and estimation strategy. Section 5 describes the data. Section 6 discusses the empirical results and validity tests. We conclude with Section 7 .

\section{Related literature}

This paper relates to two strands of literature. First, we contribute to the literature that has analyzed the effectiveness of fiscal rules. ${ }^{6}$ Indeed, a number of empirical studies have tried to evaluate whether fiscal rules are associated with sounder budget outcomes, reaching mixed conclusions. The evidence primarily comes from cross-country comparisons in specific regions, such as the European Union (see Hallerberg and Von Hagen, 1999; Debrun et al., 2008) or Latin America (see Alesina, Hausmann, Hommes, and Stein, 1996), and from local governments in a federal state, such as the U.S. (see Poterba, 1994; 1996). ${ }^{7}$ While some studies find that fiscal rules do indeed result in lower budget imbalances (e.g., see Knight, 2000), others stress the reasons for which fiscal restraints might not be effective (e.g., see Alesina and Perotti, 1999). ${ }^{8}$ We provide a quasi-experimental design where the effectiveness of fiscal rules is evaluated by controlling for omitted factors that may affect previous results, such as the fact that more disciplined constituencies introduce tighter rules, or that (current and past) legal institutions are endogenous to cultural values. ${ }^{9}$

\footnotetext{
${ }^{6}$ For surveys, see Poterba and Von Hagen (1999), Rodden, Eskeland, and Litvack (2003), and Wyplosz (2012). For an extensive review on the types of rules and the main empirical evaluations of their impact, see IMF (2009). Balassone, Franco, and Zotteri (2004) review the literature on subnational fiscal rules in the European Union. As we focus on local governments, our results are particularly relevant for the literature that has emphasized that the implementation of subnational fiscal rules faces serious commitment problems, in the form of future overhaul, soft budget constraints, and lack of enforcement: see, among others, Eichengreen and von Hagen (1996), Braun and Tommasi (2004), Sutherland et al. (2005), and Ter-Minassian (2007).

${ }^{7}$ Studies on the U.S. include Von Hagen (1991), Alt and Lowry (1994), Bayoumi and Eichengreen (1995), Bohn and Inman (1996), Alesina and Bayoumi (1996), Auerbach (2006), and Fatas and Mihov (2006).

${ }^{8}$ Knight (2000) uses the difficulty of amending U.S. state constitutions as an instrument for analyzing the effect of supermajority requirements for tax increases on tax rates.

${ }^{9}$ On the endogenous determination of laws, see Aghion, Alesina, and Trebbi (2004) and Givati and Troiano (2011). From a theoretical perspective, other authors analyze the welfare effect of fiscal restraints: Besley and Smart (2007) study limits on the size of government in a two-period agency model; Bassetto and Sargent (2006) study the welfare case for allowing the government to issue debt only to finance certain expenditures.
} 
Secondly, we contribute to the large literature on the political economy of deficit determination, as we identify a set of politicians' and voters' characteristics associated with larger deficit bias. ${ }^{10}$ From a normative perspective, it is not obvious whether tight rules such as a balanced budget requirement are optimal or not. As discussed above, restricting fiscal policy is not the first best in standard macroeconomic models without political distortions. However, restricting fiscal policy might become optimal when deficit is the suboptimal result of the interplay between rational politicians, voters, and interest groups (such as the aforementioned Alesina and Tabellini, 1990; Persson and Svensson, 1989; Aghion and Bolton, 1990; Besley, 2007; Battaglini and Coate, 2008; Song, Soresletten and Zilibotti, 2012). ${ }^{11}$ These models deliver different predictions on the types of polities where one should expect the emergence of larger deficits. Our empirical findings shed new light on these dimensions.

\section{Institutional framework}

The Italian municipal government (Comune) is composed of a mayor (Sindaco), an executive committee (Giunta) that is appointed by the mayor, and an elected city council (Consiglio Comunale) that must endorse the annual budget proposed by the mayor. The mayor and the executive committee - whose members can be dismissed by the mayor at will-propose changes in fiscal policy, such as adjustments in the tax rates. Subsequently, the city council votes on the proposed changes. Since 1993, mayors are directly elected (with single round plurality rule in cities below 15,000 inhabitants) and face a two-term limit. Municipalities manage about 10 percent of total public expenditure and are in charge of a wide range of services, including water supply, waste management, municipal police, infrastructures, welfare, and housing. Only about 20 percent of revenues are local revenues.

After the European Union adopted its Stability and Growth Pact in 1997, some European countries - including Italy — adopted subnational fiscal rules to keep local governments accountable. In December 1998, the Italian annual budget law (Legge Finanziaria) for 1999 introduced a set of rules that constrained all municipalities in terms of fiscal discipline, the aforementioned Domestic Stability Pact or DSP (Patto di Stabilità Interno). ${ }^{12}$

\footnotetext{
${ }^{10}$ This literature has been reviewed by Alesina and Perotti (1999).

${ }^{11}$ Other political economy models on deficit determination include Tabellini and Alesina (1990), Lizzeri (1999), Azzimonti, Battaglini, and Coate (2008), and Yared (2010).

${ }^{12}$ See Law 23 December 1998, no. 448, article 28.
} 
Municipal governments were constrained to keep the growth of their fiscal gap - defined as deficit, net of transfers and debt service - under tight control. The rationale for the exclusion of debt service and transfers in the definition of the DSP target is twofold. First, mayors are not accountable for expenses on interests (which depend on previously contracted loans) and for revenues from transfers (which are not raised by the municipality). Second, these two items are the tools that the central government uses to enforce fiscal rules, reducing interest payments for compliers and cutting transfers for non-compliers. The punishment established for not complying with the DSP included the following penalties: (i) 5 percent cut in the annual transfers from the central government; (ii) ban on municipal hires; (iii) 30 percent cut on reimbursement and non-absenteeism bonuses for the employees of the municipal administration. Cities complying with the DSP, instead, benefited from a reduction of the expenses on interests for loans from the central government. ${ }^{13}$

The exact DSP rule constraining the fiscal gap changed from one year to another, but over our sample period it consisted in imposing a cap on the growth rate of the gap. Table 1 summarizes the evolution of the DSP over our sample period. The cap varies between a minimum of zero (no growth allowed) and a maximum of 3 percent, the benchmark being the fiscal gap two years before the actual budget year (this means that, for instance, the growth rate in 2004 is calculated with respect to the fiscal gap in 2002).

In evaluating the impact of the DSP on fiscal discipline, we therefore focus on the pattern of both deficit and fiscal gap. Constrained and unconstrained municipalities can accumulate debt, but if they run into fiscal distress they need to go through a special procedure of budget consolidation (Piano di Risanamento). One possible concern can be that relaxing fiscal rules induces expectations in our treated cities that they will be bailed out in case of situations of fiscal distress. ${ }^{14}$ While we acknowledge the possibility that changes in fiscal restraints can always be confounded with changes in expectations, both legal and anecdotal evidence

\footnotetext{
${ }^{13}$ Consistently with the law, we compute fiscal gap with the formula: Fiscal Gap = (Total Expenditures Debt Service) - (Total Revenues - Transfers). See the Appendix Table A1 for more details on the definition of policy outcomes. Unfortunately, the Ministry of the Interior does not release the list of municipalities that did not comply with the rule according to its records. As discussed in Section 6.1, we find suggestive evidence that the DSP penalties were enforced, as there is a correlation between non-compliance (as estimated in our data) and lower transfers (which are the main DSP enforcement mechanism).

${ }^{14}$ In general, Italian municipalities can finance their debt through the emission of bonds (Buoni Obbligazionari Comunali) or with loans from a central administrative agency (Cassa Depositi e Prestiti) and from private banks.
} 
are consistent with the view that the Italian government made substantive effort to keep expectations of bailing out as low as possible in the period of interest. In 2001, the Italian Constitution undertook a substantial revision that tried to introduce a higher degree of fiscal decentralization while making bailouts unconstitutional. ${ }^{15}$

After 2001, all municipalities below 5,000 inhabitants were exempted by the DSP. ${ }^{16}$ The motivation for this exemption was not made explicit by the central government, but it is probably linked to the goal of providing some relief to small municipalities in the presence of economies of scale in managing the municipal government. Fiscal rules, however, are not the only policy varying with population size at 5,000. In particular, at this cutoff, there is a sharp increase in the wage received by the mayor and by the other members of the executive committee, based on a remuneration policy that has been in place since the early 1960s. Gagliarducci and Nannicini (2012) show that the wage increase at 5,000 attracts more educated individuals into politics and improves their performance once elected. Table 2 summarizes all the Italian policies on municipal governments relying on population thresholds over our sample period. Population size determines the size of the city council; the size of the executive committee; the electoral rule; and whether a municipality can have additional elective bodies at the neighborhood level. But only the DSP (after 2001) and the salary of local politicians display a discontinuity at the 5,000 cutoff.

In 2002, regions with special autonomy (Regioni a Statuto Speciale) were allowed to set their own fiscal rules for municipal governments, and this is why we do not consider these regions in our study. Furthermore, since 2005 fiscal rules have been frequently changing from one year to another, shifting the population cutoff from 5,000 to 3,000 and back, and replacing the fiscal gap requirement with expenditure caps in some years. This is the reason why we focus our empirical evaluation on the period from 1997 to 2004.

In the next section, we explain how we exploit these unique Italian institutions to identify the effect of fiscal restraints on fiscal discipline.

\footnotetext{
${ }^{15}$ The new article 119 of the Italian Constitution specifically forbids the increase of governmental transfers to local governments in fiscal distress. Anecdotal evidence confirms a hard-line stance by the central government toward indebted municipalities. For instance, Taranto, a medium sized Italian city, declared bankruptcy in 2006; local newspapers reporting on the fiscal situation of the city (e.g., see Taranto Sera) stressed how the city had to undertake a multi-year repayment plan, without any help from the central government, and, after six years, almost half of the debt was still outstanding; public services and wage of public employees were suspended for some months after the bankruptcy, and local tax rates were significantly raised.

${ }^{16}$ See Law 23 December 2000, no. 388, article 53.
} 


\section{Difference-in-discontinuities design}

\subsection{Setup}

Define $Y_{i t}(1)$ as the potential policy outcome of municipality $i$ at time $t$ in the case of treatment $\left(D_{i t}=1\right)$, and $Y_{i t}(0)$ as the potential policy outcome of the same municipality at the same time in the case of no treatment $\left(D_{i t}=0\right)$. Because of the institutions described above, the treatment $D_{i t}$ coincides with "relaxing fiscal rules." The treatment year is $T_{0}$ (2001, in our setting): that is, if $t \geq T_{0}$, only municipalities below a certain population cutoff $P_{c}$ are treated; the running variable $P_{i}$ is set at the Census level and therefore time-invariant. Formally, treatment assignment is given by:

$$
D_{i t}= \begin{cases}1 & \text { if } P_{i} \leq P_{c}, t \geq T_{0} \\ 0 & \text { otherwise }\end{cases}
$$

It would be tempting to implement a cross-sectional RD design and estimate the discontinuity in the observed outcome $Y_{i t}$ at $P_{c}$ after $T_{0}$. Unfortunately, as discussed above, Italian institutions show a confounding policy discontinuity at $P_{c}$, because local politicians just above this threshold receive a higher wage. This means that the standard RD assumption of continuity of potential outcomes (see Hahn, Todd, and Van der Klaauw, 2001 ) is not verified in a cross-sectional sense. To formalize our argument and keep notation simple, define the following quantities: $\mathrm{y}_{\mathrm{k}}^{-} \equiv \lim _{\epsilon \rightarrow 0} E\left[Y_{i t}(k) \mid P_{i}=P_{c}-\epsilon, t \geq T_{0}\right]$, $\mathrm{y}_{\mathrm{k}}^{+} \equiv \lim _{\epsilon \rightarrow 0} E\left[Y_{i t}(k) \mid P_{i}=P_{c}+\epsilon, t \geq T_{0}\right]$, with $k \in\{0,1\}$. The presence of a confounding policy discontinuity at $P_{c}$ implies that: $\Gamma_{0} \equiv \mathrm{y}_{0}^{-}-\mathrm{y}_{0}^{+} \neq 0$, and $\Gamma_{1} \equiv \mathrm{y}_{1}^{-}-\mathrm{y}_{1}^{+} \neq 0$.

What does the cross-sectional RD estimator identifies after $T_{0}$ ? To see this, define the following average treatment effects in a neighborhood of the threshold $P_{c}$.

Definition. The quantity $\left(\mathrm{y}_{1}^{-}-\mathrm{y}_{0}^{-}\right)$represents the Neighborhood Average Treatment effect on the Treated (NATT). The quantity $\left(\mathrm{y}_{1}^{+}-\mathrm{y}_{0}^{+}\right)$represents the Neighborhood Average Treatment effect on the Untreated (NATU). Under the homogeneity condition that $\left(\mathrm{y}_{1}^{-}-\mathrm{y}_{0}^{-}\right)=\left(\mathrm{y}_{1}^{+}-\mathrm{y}_{0}^{+}\right)$, both quantities represent the Neighborhood Average Treatment Effect (NATE).

In words, the NATT (NATU) captures the effect of relaxing fiscal rules for municipalities just below (above) $P_{c}$; the NATE captures this effect in a symmetric neighborhood of $P_{c}$. 


\subsection{Identification}

The cross-sectional RD estimator is defined as the discontinuity in the observed outcome $Y_{i t}$ at $P_{c}$, that is, $\left(\mathrm{y}^{-}-\mathrm{y}^{+}\right)$. It is straightforward to show that this estimator, given that $\mathrm{y}^{-}=\mathrm{y}_{1}^{-}$ and $\mathrm{y}^{+}=\mathrm{y}_{0}^{+}$, identifies either the NATT plus the confounding discontinuity for the treated, or the NATU plus the confounding discontinuity for the untreated:

$$
\begin{aligned}
& \mathrm{y}^{-}-\mathrm{y}^{+}=\mathrm{y}_{1}^{-}-\mathrm{y}_{0}^{-}+\mathrm{y}_{0}^{-}-\mathrm{y}_{0}^{+}=N A T T+\Gamma_{0}, \\
& \mathrm{y}^{-}-\mathrm{y}^{+}=\mathrm{y}_{1}^{+}-\mathrm{y}_{0}^{+}+\mathrm{y}_{1}^{-}-\mathrm{y}_{1}^{+}=N A T U+\Gamma_{1} .
\end{aligned}
$$

If the effect of the confounding policy is equal for the treated and untreated $\left(\Gamma \equiv \Gamma_{1}=\Gamma_{0}\right)$, it follows that: $\mathrm{y}^{-}-\mathrm{y}^{+}=N A T E+\Gamma$. This means that the cross-sectional RD estimator gives biased estimates of any causal effect of relaxing fiscal rules.

However, information on the pre-treatment period $\left(t<T_{0}\right)$ allows us to remove the bias under mild assumptions. Analogously to the post-treatment period, define: $\tilde{\mathrm{y}}_{\mathrm{k}}^{-} \equiv$ $\lim _{\epsilon \rightarrow 0} E\left[Y_{i t}(k) \mid P_{i}=P_{c}-\epsilon, t<T_{0}\right], \tilde{\mathrm{y}}_{\mathrm{k}}^{+} \equiv \lim _{\epsilon \rightarrow 0} E\left[Y_{i t}(k) \mid P_{i}=P_{c}+\epsilon, t<T_{0}\right]$, with $k \in\{0,1\}$. To identify the causal effect of relaxing fiscal rules, we implement an estimator that exploits both the (sharp) discontinuous variation at $P_{c}$ and the time variation after $T_{0}: \hat{\tau} \equiv\left(\mathrm{y}^{-}-\mathrm{y}^{+}\right)-\left(\tilde{\mathrm{y}}^{-}-\tilde{\mathrm{y}}^{+}\right) .{ }^{17}$ We call $\hat{\tau}$ "difference-in-discontinuities" estimator because it rests on the intuition of combining a difference-in-differences strategy and an RD design.

Assumption 1. The confounding discontinuity is constant over time: $\mathrm{y}_{0}^{-}-\mathrm{y}_{0}^{+}=\tilde{\mathrm{y}}_{0}^{-}-\tilde{\mathrm{y}}_{0}^{+}$.

This assumption is equivalent to the RD assumption that potential outcomes are continuous, as it states that the difference in $Y_{i t}(0)$ before and after $T_{0}$ is continuous at $P_{c}$. Assumption 1 requires the effect of the wage policy not to vary with time. This assumption allows us to estimate the discontinuity in $Y_{i t}(0)$ before $T_{0}$ and then remove it from the observed discontinuity after $T_{0}$, so as to identify the causal impact of relaxing fiscal rules.

\footnotetext{
${ }^{17}$ There exist alternative approaches that exploit the longitudinal nature of the data in a regression discontinuity setting, such as the fixed-effect RD estimator used by Pettersson-Lidbom (2012), the firstdifference RD estimator used by Lemieux and Milligan (2008), or the dynamic RD design in the presence of repeated spells of treatment assignment by Cellini, Ferreira, and Rothstein (2011). In all of these cases, however, treatment assignment changes over time because the running variable is not constant, and not because the policy threshold has changed as in our diff-in-disc design. Our econometric strategy also relates to those evaluation designs that exploit the comparison between different discontinuities across space, such as in different U.S. states (see Dickert-Conlin and Elder, 2010) or for politicians facing different term limits (see Gagliarducci and Nannicini, 2012). The time variation embedded in the diff-in-disc design, however, has specific implications for the identifying assumptions and for the diagnostics tools (see below).
} 
Proposition 1. Under Assumption 1, the diff-in-disc estimator identifies the NATT.

Proof. $\hat{\tau} \equiv\left(\mathrm{y}^{-}-\mathrm{y}^{+}\right)-\left(\tilde{\mathrm{y}}^{-}-\tilde{\mathrm{y}}^{+}\right)=\left(\mathrm{y}_{1}^{-}-\mathrm{y}_{0}^{-}\right)+\left(\mathrm{y}_{0}^{-}-\mathrm{y}_{0}^{+}\right)-\left(\tilde{\mathrm{y}}_{0}^{-}-\tilde{\mathrm{y}}_{0}^{+}\right)=\mathrm{y}_{1}^{-}-\mathrm{y}_{0}^{-}=N A T T$.

Assumption 1 is plausible in our setting, but it can nevertheless be verified by indirect testing procedures as is the case for the (cross-sectional) RD continuity condition.

Note that the above estimand is local in a twofold manner, because it involves the subpopulation hit by the interaction of two policies: the treatment and the confounding discontinuity. In our case, it captures the effect of relaxing fiscal rules for mayors with a lower wage. Under an additional homogeneity assumption, the diff-in-disc estimator identifies the NATE, which is the standard estimand in cross-sectional RD: that is, a treatment effect that is still local but more general than the $N A T T$, as it refers to the entire neighborhood of $P_{c}$.

Assumption 2. The confounding discontinuity is the same with and without treatment: $\mathrm{y}_{1}^{-}-\mathrm{y}_{1}^{+}=\mathrm{y}_{0}^{-}-\mathrm{y}_{0}^{+}$.

Proposition 2. Under Assumptions 1 and 2, the diff-in-disc estimator identifies the NATE.

Proof. Because of Assumption 1, $\hat{\tau}=N A T T$. At the same time, because of both Assumptions 1 and $2: \hat{\tau} \equiv\left(\mathrm{y}^{-}-\mathrm{y}^{+}\right)-\left(\tilde{\mathrm{y}}^{-}-\tilde{\mathrm{y}}^{+}\right)=\left(\mathrm{y}_{1}^{+}-\mathrm{y}_{0}^{+}\right)+\left(\mathrm{y}_{1}^{-}-\mathrm{y}_{1}^{+}\right)-\left(\mathrm{y}_{0}^{-}-\mathrm{y}_{0}^{+}\right)=\mathrm{y}_{1}^{+}-\mathrm{y}_{0}^{+}=$ $N A T U$. Therefore: $N A T T=N A T U=N A T E$.

Assumption 2 states that there must be no interaction between the treatment and the confounding discontinuity, and - in a sense - is equivalent to the additivity condition in difference-in-differences (see Angrist and Krueger, 1998). In our institutional setting, this assumption would be violated if mayors just below and above $P_{c}$, who are paid differently, reacted to fiscal rules in a different way. Fortunately, under the maintained hypothesis that Assumption 1 holds, this second assumption is testable, because of the introduction of fiscal rules for everybody in 1999 (see the previous section). As a matter of fact, it is simple to show that - by applying the diff-in-disc design to 1999, when there is no discontinuity in fiscal rules at $P_{c}$ - we can test whether the jump before 1999 (which estimates $\mathrm{y}_{1}^{-}-\mathrm{y}_{1}^{+}$) is equal to the jump between 1999 and 2001 (which estimates $\mathrm{y}_{0}^{-}-\mathrm{y}_{0}^{+}$). In other words, for this falsification test in 1999, the diff-in-disc estimator should deliver a zero effect. 
Finally, note that - because of the institutions described in the previous section-our diff-in-disc design can only identify the effect of relaxing fiscal rules for small Italian municipalities. Therefore, interpreting our estimates as the effect of imposing fiscal rules in the same setting would require an additional symmetry assumption.

\subsection{Estimation and diagnostics}

The diff-in-disc estimator takes the difference between two discontinuities in the observed outcome $Y_{i t}$ - one after $T_{0}$ and one before $T_{0}$-and can be implemented by estimating the boundary points of four regression functions of $Y_{i t}$ on $P_{i}$ : two on both sides of $P_{c}$, before and after $T_{0}$. We borrow two different estimation methods from the RD literature for this purpose: local linear regression and spline polynomial approximation. ${ }^{18}$

The first method fits linear regression functions to the observations distributed within a distance $h$ on either side of $P_{c}$, both before and after $T_{0}$. Formally, we restrict the sample to cities in the interval $P_{i} \in\left[P_{c}-h, P_{c}+h\right]$ and estimate the model:

$$
Y_{i t}=\delta_{0}+\delta_{1} P_{i}^{*}+J_{i}\left(\gamma_{0}+\gamma_{1} P_{i}^{*}\right)+T_{t}\left[\alpha_{0}+\alpha_{1} P_{i}^{*}+J_{i}\left(\beta_{0}+\beta_{1} P_{i}^{*}\right)\right]+\xi_{i t},
$$

where $J_{i}$ is a dummy for cities below $5,000, T_{t}$ an indicator for the post-treatment period, and $P_{i}^{*}=P_{i}-P_{c}$ the normalized population size. Standard errors are clustered at the city level. The coefficient $\beta_{0}$ is the diff-in-disc estimator and identifies the treatment effect of relaxing fiscal rules, as the treatment is $D_{i t}=J_{i} \cdot T_{t}$. As suggested by Imbens and Lemieux (2008) and due to a lack of consensus on how to choose an optimal bandwidth, we present the robustness of our results to multiple bandwidths $h$.

The second method uses all observations and chooses a flexible functional form to fit the relationship between $Y_{i t}$ and $P_{i}$ on either side of $P_{c}$, both before and after $T_{0}$ :

$$
Y_{i t}=\sum_{k=0}^{p}\left(\delta_{k} P_{i}^{* k}\right)+J_{i} \sum_{k=0}^{p}\left(\gamma_{k} P_{i}^{* k}\right)+T_{t}\left[\sum_{k=0}^{p}\left(\alpha_{k} P_{i}^{* k}\right)+J_{i} \sum_{k=0}^{p}\left(\beta_{k} P_{i}^{* k}\right)\right]+\xi_{i t} .
$$

Again, standard errors are clustered at the city level, and the coefficient $\beta_{0}$ is the diff-in-disc estimator identifying the treatment effect of relaxing fiscal rules. We present the robustness of our results to multiple orders of the polynomial approximation $(p)$.

\footnotetext{
${ }^{18}$ See Imbens and Lemieux (2008), Van der Klaauw (2008), and Lee and Lemieux (2010).
} 
A nice feature of the diff-in-disc design is that it provides a vast array of tests that can validate the underlying identification strategy. First, as discussed above, the generalized introduction of fiscal rules in 1999 allows us to test for the lack of interactive effect between the treatment and the pre-existing policy discontinuity. Second, it is important to check whether any manipulation of the running variable changes (or arises) over time. In other words, the cross-sectional test of continuity of the density at $P_{c}$ (see McCrary, 2008) should be extended to test for the continuity of the difference in the densities before and after $T_{0}$. Third, diff-in-disc estimations with time-invariant characteristics as outcomes should be implemented to indirectly test for changes in the pattern of manipulative sorting, because the mean difference of these characteristics just below and above $P_{c}$ is not supposed to vary after $T_{0}$ in the absence of manipulation. Fourth, as a further check in this direction, time-invariant characteristics and year fixed effects should be included as covariates in the baseline diff-in-disc estimations; in the absence of manipulation, point estimates are expected to remain similar and accuracy to increase. Fifth, placebo diff-in-disc estimations should be implemented at false (or time-invariant) cutoffs, where placebo point estimates should be systematically smaller than the baseline point estimates.

\section{Data}

We use administrative data from the Italian Ministry of the Interior (Ministero dell'Interno) containing information at the municipality level on the universe of municipal financial reports, municipal tax rates, electoral outcomes, and individual characteristics of the mayor. Based on the local nature of our diff-in-disc design, we restrict the sample to Italian municipalities between 3,500 and 7,000 inhabitants. ${ }^{19}$ For the reason discussed in Section 3, we drop municipalities in regions with special autonomy. This leaves us with a final sample of 1,050 municipalities for a total of 6,300 observations from 1999 to 2004. Among them, 555 municipalities are treated after 2001 (because they are below 5,000 inhabitants) and 495 are in the control group. Our sample contains about 13 percent of all Italian municipalities and about 8 percent of the national population.

\footnotetext{
${ }^{19}$ We restrict the sample to the interval $3,500-7,000$ to stay relatively far from the 3,000 threshold, where other policies change (see Table 2), and to balance the sample size on either side of the 5,000 threshold. All the results are robust to this interval choice, i.e., they are virtually unchanged for alternative choices, such as $3,250-6,750 ; 3,000-7,000 ; 3,500-6,500 ; 4,000-6,000$; and 3,500-7,500 (available upon request).
} 
The population size that decides treatment status is the 2001 Census. Because the relaxation of the DSP was decided in December 2000, it is very unlikely that municipalities had the time to influence their population and sort below the 5,000 threshold, and - on top of this - it is also unlikely that elected officials wanted to do that at the price of cutting their wage. In any case, in Section 6.2, we formally test for manipulative sorting below 5,000 before/after 2001 by comparing population size in the 1991 and 2001 Census.

The main variables of interest are the municipal financial report's categories. To measure fiscal discipline, we evaluate the deficit (total expenditures minus total revenues) and the fiscal gap (total expenditures minus total revenues, net of transfers and debt service), which is the target of the DSP. We divide expenditures into current outlays (including personnel expenditure), capital outlays (mostly investments), and debt service; and we divide revenues into municipal taxes, fees and tariffs, transfers from the central government, and other revenues. The main tax instruments decided by municipal governments are the real estate tax rate on home property (ICI), providing about 50 percent of their tax revenues, and the municipal surcharge on the personal income tax (IRPEF), amounting to about 10 percent of tax revenues. ${ }^{20}$ See the Appendix Table A1 for precise definitions and data sources of all variables from municipal financial reports.

One possible concern in evaluating the reaction of policies and tax instruments to fiscal rules might be that mayors have very little autonomy in adjusting local revenues or expenditure, but this is not the case for Italian municipalities. On the revenues side, over our sample period, mayors could vary ICI within a bracket from 0.4 to 0.7 percent of the legal home value, and the IRPEF surcharge within a bracket from 0 to 0.5 percent of taxable income. ${ }^{21}$ And they were also free to set other local taxes (such as those on building rights or the occupation of public areas), or fees and tariffs for the services they provided (such as waste management or child care). Additionally, Italian towns are characterized by a sizable level of tax evasion, which the mayor can decide to fight. ${ }^{22}$ On the expenditures side, municipalities

\footnotetext{
${ }^{20}$ Bordignon, Nannicini, and Tabellini (2012) also use ICI as the main policy tool of Italian municipalities.

${ }^{21}$ One additional concern can be that mayors comply with the rule by simply manipulating legal home value. However, legal home value is not determined or updated by mayors, as indicated by the DPR 22 December 1986, no. 917. Only in 2005, not in our sample, the Law 23 December 2005, no. 266 gave to municipalities some weak power of requesting the update of the assessed value of the real estate tax base.

${ }^{22}$ Casaburi and Troiano (2012) find that in 2007 over 2 millions of Italian buildings were not registered in the cadastral maps and thus were not part of the tax base for real estate and income tax.
} 
also have room for adjustment because about one third of the expenditures are classified as not rigid (that is, not attributable to payroll expenses and debt service). For instance, one way to reduce expenditures without affecting the level of services is outsourcing (e.g., child care provided by private firms with more labor flexibility and lower costs although the financing remains public). Furthermore, Bandiera, Prat, and Valletti (2009) show how similar Italian municipalities can pay very differently for similar goods, and they interpret this as evidence of passive waste. This implies that, even if all current expenditures were rigid (and this is not certainly the case), mayors would still have the ability to reduce passive waste in order to adjust the fiscal gap.

Our dataset also contains time-invariant information on each municipality (geographic location, area size in $\mathrm{km}^{2}$, sea level in meters), as well as time-varying information on the elected mayor (age, years of schooling, tenure in office, term limit), on the socio-economic environment (taxable income of resident inhabitants, age structure of the population), and on the political environment (number of political parties seating in the city council). See again the Appendix Table A1 for their description and sources.

Table 3 provides descriptive statistics on the main outcome variables (policy outcomes and tax instruments) for cities below and above 5,000 inhabitants. All variables are per capita and expressed in real terms (with 2009 as base year); tax rates are in percentage points. Municipalities below (above) 5,000 manage an annual budget equal to almost 1,041 (943) Euros per capita in terms of expenditures, and the deficit amounts to about 15 (11) Euros. Taxes are only slightly lower than 20 percent of total revenues and higher in municipalities above 5,000. The main tax rates on ICI and the IRPEF surcharge, however, are fairly similar for municipalities in the two groups.

As a benchmark, note that applying a difference-in-differences strategy to our dataset delivers the expected result: relaxing fiscal rules increases the deficit by 6.276 Euros and the fiscal gap by 48.278 Euros in a specification without municipality fixed effects, and by 5.279 and 16.669 with fixed effects, where both estimates on deficit are statistically significant at a 5 percent level and those on fiscal gap at a 1 percent level. However, in the next section, we discuss the results of our diff-in-disc design, which provides more credible evidence on the impact of relaxing fiscal rules on fiscal discipline for the reasons discussed above. 


\section{Empirical results}

\subsection{Effect of relaxing fiscal rules on policy outcomes}

Table 4 contains the main (diff-in-disc) estimation results. For each outcome variable, we show the robustness of the results to four estimation methods: local linear regression as in equation (4) with two different bandwidths (i.e., 500 and 750); spline polynomial approximation as in equation (5) with two different orders of the polynomial (i.e., $3^{\text {rd }}$ and $4^{\text {th }}$ ). ${ }^{23}$ The main outcomes of interest are the two measures of fiscal discipline: deficit and fiscal gap (see panel A of the table). While the latter is the main target of the DSP, we believe that the former should be the real variable of policy interest.

The impact of relaxing rules on the deficit is positive and significant both in statistical and in economic terms. The DSP relaxation increases deficit by about 20 Euros per capita with respect to a baseline situation of balanced budget. The deficit bias created by the relaxation of the DSP is also substantial from an economic point of view, as it amounts to about 2 percent of total expenditures. This effect is driven by a higher fiscal gap of about 40 to 60 percent, depending on the empirical specification. Both these effects are statistically significant at standard levels in all specifications, and the point estimates of the deficit are somehow more stable than those of fiscal gap.

These estimation results on fiscal discipline are consistent with the descriptive graphs shown in Figure 1 (deficit) and in Figure 2 (fiscal gap), where we draw scatters and ( $3^{\text {rd }}$-order) polynomial fits of the differences between each post-2001 outcome value and each pre-2001 value. These graphs allow us to see whether those differences exhibit a discontinuity at the 5,000 threshold. We see that both variables measuring fiscal discipline exhibit a sharp jump when moving from the left to the right of the threshold in the whole sample (top left graph in both figures). Furthermore, in the other graphs in Figure 1 and Figure 2, we shed some light on the timing of the effect; we redraw the scatters and polynomial fits considering in the post-treatment period only observations after 2001 (top right), 2002 (bottom left), and 2003

\footnotetext{
${ }^{23}$ Results are robust to the use of additional bandwidths (i.e., 250 and 1,000) or additional orders of the polynomial (i.e., $2^{\text {nd }}$ and $5^{\text {th }}$ ) and are available upon request. We use the two estimation methods that are standard in the RD literature. However, to address concerns about the sensitivity of our results to functional form assumptions, we also repeated the analysis implementing a simple t-test of the difference-indiscontinuities in closed intervals around the threshold (with intervals getting smaller and smaller) and we always obtained a difference statistically different from zero (results available upon request).
} 
(bottom right). The evidence is consistent for both deficit and fiscal gap, as the adjustment accelerates in 2002 and 2003 but slows down in 2004 (patterns that can be consistent with municipalities eventually realizing that the punishment is less harsh than expected). The observed discontinuities, however, remain statistically significant for all years. ${ }^{24}$

In panels $\mathrm{B}$ and $\mathrm{C}$ of Table 4, we assess whether the fiscal (de)stabilization takes place on the side of revenues or expenditure. While we cannot find a statistically significant impact on current outlays, capital outlays, and debt service, we find that tax revenues are lower by 20 to 45 percent in unconstrained municipalities (with respect to the average value of the control group and depending on the specification). Lower tax revenues are the result of lower tax rates decided by the municipal government (see panel D of Table 4). Cities for which fiscal rules are relaxed have a lower real estate tax rate by 14 percent and a lower income tax surcharge by 30 percent. Other revenues do not seem to be affected by the relaxation of fiscal restraints. ${ }^{25}$

Also on the side of revenues, central transfers seem to be higher for unconstrained municipalities, although point estimates are not always statistically significant. This result cannot explain the above impact of relaxing fiscal rules on fiscal discipline because it goes in the opposite direction (that is, local governments running higher deficits receive larger transfers), and it is consistent with the design of the law, which allows the central government to cut transfers as an enforcement mechanism. This conjecture is consistent with our data. Although the Italian government did not release the official list of complying and non-complying municipalities, we can estimate compliance status in every year by applying the official rule summarized in Table 1 to our data. We find that complying municipalities amount to $68 \%$ of the total, and non-complying municipalities are also present around the 5,000 threshold, where the estimated compliance status shows a sharp discontinuity of about $40 \% .{ }^{26}$ Future

\footnotetext{
${ }^{24}$ The yearly diff-in-disc estimates for 2001, 2002, 2003, and 2004 confirm the above graphical evidence on the timing of the effect of relaxing fiscal rules on fiscal discipline (available upon request).

${ }^{25}$ Other revenues include transfers from the European Union, other transfers, mortgages from administrative agencies, revenues coming from private properties owned by the municipality. Even if the standard errors for other revenues are bigger than the rest of our variables, visual inspection of the corresponding graph in Figure 3 reveals that standard errors are driven up by an outlier in this category. Repeating our analysis without this outlier consistently reduces the standard errors without affecting the other outcomes (results available upon request).

${ }^{26}$ Specifically, if we repeat our RD estimations using compliance status as a dependent variable, we obtain the following results for local linear regression $(h=500, h=750)$ and spline polynomial approximation $\left(3^{r d}\right.$ and $4^{\text {th }}$ order), respectively: 0.450 (standard error, 0.070); 0.443 (0.054); $0.448(0.076) ; 0.436(0.096)$.
} 
transfers appear to be strongly correlated with compliance status: in a specification that controls for year fixed effects, central transfers are larger by about 10.329 Euros per capita (standard error, 3.303) for complying municipalities. ${ }^{27}$ This evidence is consistent with the institutional details discussed in Section 3, according to which central transfers are used as the main enforcement device of the DSP.

Figure 3 provides graphical evidence on the diff-in-disc jumps at the 5,000 threshold in the policy outcomes and tax instruments; the graphs refer to the entire post-treatment period and are constructed like the top left graphs in Figure 1 for deficit and in Figure 2 for fiscal gap. Consistently with the estimation results, tax revenues, ICI, and IRPEF show significant and negative jumps moving from just above to just below the 5,000 residents threshold. The graphs on expenditures confirm that these variables are reasonably stable across the threshold, even if the size of the standard errors in Table 4 does not allow us to reach a definitive conclusion on the possibility that a fraction of the adjustment also takes place through expenditures.

The previous results suggest that the fiscal adjustment mainly takes place on revenues. There are (at least) two possible explanations that can rationalize this finding. On the one hand, politicians might have a hard time convincing interest groups to cut expenditures, while taxpayers are more prone to internal free-riding and do not self-organize (see Olson, 1965). On the other hand, tax increases might be less salient than expenditure cuts for individuals (see Chetty, Looney, and Kroft, 2009) and thus they might be easier to adopt (or revert) for politicians.

\subsection{Validity tests}

As discussed in Section 4, the above estimation results rest on Assumption 1 and Assumption 2 for the identification of different average treatment effects in the neighborhood of the population threshold. In this section, we indirectly evaluate Assumption 1 by means of testing procedures aimed at detecting changes in manipulative sorting before/after 2001, and we directly test Assumption 2 in the falsification test that uses pre-treatment data.

The Appendix Figure A1 tests the null hypothesis of continuity of the difference in the density at 5,000 between the 1991 and the 2001 Census (top graph), by drawing both scatters

\footnotetext{
${ }^{27}$ Results are robust to the use of municipality fixed effects.
} 
and $\left(3^{r d}\right.$-order $)$ polynomial fits. If mayors were able to manipulate population size and sort below the threshold to avoid fiscal rules, our estimates would still suffer from the selection bias that was common in the previous empirical literature. However, in principle, there is very little room for differential manipulation between the two Censuses, because (i) the DSP is only enacted in December 2000, (ii) the Census is run independently by the National Statistical Office, so that false reporting should be ruled out, and (iii) mayors willing to sort below 5,000 to enjoy a relaxation of fiscal rules would pay the price of cutting their wage. Nevertheless, it might still be the case that some municipalities under financial stress tried to sort below 5,000 moving from the 1991 to the 2001 Census, by forcing some residents to leave or (more plausibly) not counter-reacting to population drops. Yet, the top graph in Figure A1 is reassuring about the absence of manipulation, as there is no jump in the difference between the two densities. The point estimate from the spline polynomial approximation is equal to -0.078 (standard error, 0.114) and therefore is not statistically different from zero. For the sake of completeness, we also report the cross-sectional density tests for 1991 (bottom left) and 2001 (bottom right). Also there, there is no evidence of manipulation. ${ }^{28}$

Furthermore, in the Appendix Table A2, we check for the balancing of time-invariant characteristics by including covariates, together with year fixed effects, in the baseline diff-in-disc estimations; as expected, point estimates remain almost unchanged and accuracy increases. The Appendix Table A3 further evaluates the absence of manipulation. We implement diffin-disc estimations with time-invariant characteristics (geographic location, area size, and sea level) as outcome variables, but we use changing population numbers: the 1991 Census before the treatment year, and the 2001 Census afterwards. This is meant to assess whether the fraction of cities with certain fixed characteristics just below or above 5,000 varies from 1991 to 2001. No time-invariant characteristics display a statistically significant jump. ${ }^{29}$ We

\footnotetext{
${ }^{28}$ The 1991 point estimate is 0.068 (0.082); the 2001 point estimate is $-0.010(0.076)$.

${ }^{29}$ As an additional check, in the Appendix Table A4, we report balance tests of potentially endogenous characteristics. We implement diff-in-disc estimations with some (time-varying) economic or political characteristics of the municipality as outcome variables, using the 2001 Census population as the running variable as in the baseline specifications for the main policy outcomes. The time-varying characteristics we control for are the taxable income at the municipality level; the mayor's gender, years of schooling, and previous tenure in office; as well as the dimension of heterogeneous treatment effects we study in the next section (namely, term limit, number of parties, young cohorts, and speed of public good provision). These outcomes are potentially endogenous to the DSP, but detecting significant effects would disclose unexpected channels of adjustment through income, political selection, or public good delivery. This does not seem to be the case, as also these potentially endogenous variables are balanced around 5,000 before/after 2001 .
} 
think that geographical location is a particularly interesting dimension here, because Italian geography is correlated with economic development, crime rates, labor market shirking, or political accountability (e.g., see Ichino and Maggi, 2000; Nannicini, Stella, Tabellini, and Troiano, 2012), and it could thus be associated with opportunistic manipulation too.

Based on this large amount of supporting evidence on Assumption 1, in Table 5 we directly test for Assumption 2 under the maintained hypothesis that Assumption 1 holds. In particular, we check whether cities just below or just above the 5,000 threshold respond differently to fiscal rules. We use the introduction of the DSP in 1999 for all municipalities as an experiment to test for the absence of any differential response around 5,000. Specifically, we implement diff-in-disc estimations in the interval 1997-2000, using 1999-2000 as the posttreatment period and 1997-1998 as the pre-treatment period. ${ }^{30}$ All outcome variables are perfectly balanced around the threshold before/after 1999, confirming the assumption that there is no interaction between the DSP and the confounding wage discontinuity. ${ }^{31}$

Finally, we perform a set of placebo tests to evaluate the possibility that our results arise from random chance rather than a causal relationship. In the Appendix Figure A2 and Figure A3, in the spirit of DellaVigna and La Ferrara (2012), we implement - respectively for deficit and for fiscal gap - a set of diff-in-disc estimations at false population thresholds below and above the 5,000 threshold (namely, any point from 4,900 to 4,400 and from 5,100 to 5,600 in order to stay sufficiently away from the true policy threshold). At these false thresholds, we expect to find no systematic evidence of treatment effects similar to our baseline results. The two figures report the cumulative density function of these 1,000 placebo point estimates (using a specification with $3^{r d}$-order spline polynomial), normalized with respect to our baseline point estimates for deficit and fiscal gap. This means, for instance, that a normalized coefficient of 80 stands for a placebo point estimate equal to 80 percent of the true baseline estimate at 5,000. The intuition here is that we should not observe

\footnotetext{
${ }^{30}$ The city of Romentino was an outlier due to a lucrative sale of land in 1998 and it was removed from the sample. Our results do not change with the inclusion of this city, with the exception of bigger standard errors for other revenues (available upon request).

${ }^{31}$ This falsification test suggests that the rule did not bind differently across the different sides of the population cutoff. We perform an additional robustness check by repeating yearly diff-in-disc estimations considering the last pre-treatment year, 2000, as the baseline year. As expected, none of the pre-treatment coefficients, from 1997 to 1999, is statistically different from the 2000 coefficient, while there is a sizable jump of the post-treatment coefficients (i.e., 2001, 2002, 2003, and 2004). This robustness check indirectly controls also for anticipation effects and for idiosyncratic variation in each single year (available upon request).
} 
too many normalized coefficients outside the interval from -100 to +100 . Indeed, all of the placebo coefficients are below our estimated coefficients for both deficit and fiscal gap, and the cumulative density function of the normalized coefficients is much steeper around zero. Only 0.8 percent of the normalized placebo coefficients for deficit is bigger than the true coefficient in absolute value, while none of them is so for fiscal gap. On the whole, these placebo tests provide strong support to the robustness of our main results on fiscal discipline.

\subsection{Political economy of fiscal adjustment}

In this section, we exploit our research design to shed light on the political economy of deficit. Evaluating the differential response of different politicians and voters to an exogenous (albeit local) variation in fiscal rules, in fact, can identify important determinants of politically motivated deficits and provide new evidence about the costs and benefits of fiscal restraints. We start by looking at three political factors. First, we consider whether there are more than two parties in the city council - which must approve the budget proposed by the mayor - to capture political fragmentation and potential common pool problems. Second, we consider whether mayors face a binding term limit or not, because mayors in their second term have no reelection incentives and no personal stake in the city's budget for the following years. Third, we consider the age profile of citizens in our municipalities. We then relate our findings to models that formalize the trade-off between reduced flexibility of fiscal policy and increased discipline on politically motivated deficit. First, we consider the effort of the mayor in providing the public good promised to voters in the provisional budget. Second, we look at cities characterized by historical deficit versus those characterized by a cyclical one.

Results for the first two variables are reported in Table 6, where we implement the baseline diff-in-disc estimations in split samples: (i) two parties in the city council (the median value) vs. more than two parties; (ii) binding vs. non-binding term limit. For each heterogeneity exercise, we report the diff-in-disc estimates in the two (split) subsamples, the difference between the two point estimates, as well as the Wald test p-value indicating whether this difference is statistically different from zero. We are aware that, while the point estimates in each subsample consistently identify local average treatment effects, the causal interpretation of their difference rests on an additional conditional independence assumption. This is why we also report a second Wald test p-value (with covariates) indicating whether this difference is 
robust to a specification including a full set of interactions with covariates at the municipality level (namely, the average taxable income; mayor's years of schooling; and whether the municipality is in the North of the country). If also this test is statistically significant, it means that the differential impact of relaxing fiscal rules across our heterogeneity dimensions is not driven by other confounding city characteristics.

First, we focus on political fragmentation. Political fragmentation generally arises when several agents have an active role in the allocation of the budget, each with its own constituency to please, and each with some weight in the final decision. There are two key determinants that affect how much a policy maker internalizes the costs of the demanded share of the budget: the number of decision makers participating in the bargaining process and the institutional rules determining the aggregation of preferences. Most empirical studies focus on the first determinant because of a lack of reliable proxies for the rules that determine the budget allocation across countries. We also follow this previous literature by focusing on the first determinant (see Kontopoulos and Perotti, 1999). However, one advantage of our setting is that we can safely assume that the rules that determine the allocation of the budget are constant around our threshold. The estimation results reported in Table 6 show that only municipalities with high political fragmentation react to the relaxation of the DSP, and this result is robust to controlling for covariates. This result is consistent with models that explain deficit in terms of political fragmentation or dynamic common pool (see Persson and Tabellini, 2000) and also with the cross-country evidence that coalition governments lead to higher deficits (see Roubini and Sachs, 1989; Kontopoulos and Perotti, 1999).

Second, we focus on term limit, exploiting the fact that Italian mayors face a two-term limit. $^{32}$ Theoretical models suggest that the expectation of a future election can affect policies because politicians who care to run again for office must please the voters sufficiently often to merit reelection (Barro, 1973; Banks and Sundaram, 1998). We find that the fiscal (de)stabilization induced by the relaxation of the fiscal restraints is driven by mayors without a binding term limit, although this result becomes borderline insignificant in some specifications that control for covariates. As mayors without term limit face both stronger reelection concerns and a higher expected probability that they (or their party) will remain in power,

\footnotetext{
${ }^{32}$ It should be noted that: (i) municipalities do not vote at the same time, and (ii) the DSP was independent of local politics because it followed agreements between the European Union and its member countries.
} 
the above result provides more support for models linking deficit to reelection incentives (see Aghion and Bolton, 1990) or to politicians' pandering to voters (see Maskin and Tirole, 2004), rather than models viewing deficit as a way to tie the hands of future governments with different political preferences (see Alesina and Tabellini, 1990; Persson and Svensson, 1989; Tabellini and Alesina, 1990). Unfortunately, we are not able to provide further empirical evidence on strategic voting models because of the lack of a clear expected reelection probability outcome in our data. ${ }^{33}$ We are also not able to rule out alternative channels that can rationalize our result on term limit, such as the possibility that political experience per se has an effect on how mayors react to the relaxation of fiscal rules, even if it is encouraging that some of the results survive to controlling for the mayor's characteristics. ${ }^{34}$

In Table 7, which has the same structure of Table 6 , we report one additional heterogeneity result along city characteristics. In particular, we implement the baseline diff-in-disc estimations in two separate subsamples: cities with a higher (i.e., above-median) fraction of young cohorts vs. the rest of the cities. Consistently with the model of Song, Storesletten, and Zilibotti (2012), deficit increases after the relaxation of the rule only in cities with a larger proportion of young citizens. Song, Storesletten, and Zilibotti (2012) propose a dynamic politico-economic theory of fiscal policy for small open economies, and we view this model as particularly relevant for our setting because small cities are a reasonably good approximation of small open economies. The main intuition of their model is that younger citizens impose a disciplining effect on fiscal policy, because they internalize the future costs of a loose fiscal policy today. Both of the above predictions are borne out by our empirical findings. ${ }^{35}$

Finally, we move to relating our results to existing models that formalize the costs and benefits of restraining fiscal policy. Besley (2007) considers fiscal rules that increase the cost of issuing public debt in an environment characterized by two types of politicians, the ones who care about smoothing busyness cycle fluctuations and those who care about reelection. Rules that are not overly restrictive will bind more on bad politicians and increase voters'

\footnotetext{
${ }^{33}$ See Petterson-Lidbom (2001) for an empirical evaluation of strategic voting models.

${ }^{34}$ Given that we can control for the selection of mayors (years of schooling), our findings provide additional support to the literature that focuses on the effect of term limit on political accountability and in-office performance (see Besley and Case, 1995; List and Sturm, 2006).

${ }^{35}$ Another testable prediction of their model is that deficit bias should be higher for cities where the mayor is affiliated with right-wing parties. While most of the mayors in our sample are not affiliated with parties that can be clearly mapped to the ideological spectrum, we also find evidence that is consistent with this prediction in the (small) subset of mayors affiliated to a political party (results available upon request).
} 
welfare. In Table 8, we split the sample based on the median of the speed of public good provision (measured as the ratio of paid outlays over the total outlays committed in the provisional budget). Our indicator of the speed of public good provision is calculated as a mayor-specific measure, averaged across all the years each mayor is in office. The results show that the increase in deficit bias arises only for mayors that systematically under-provide the public good promised to voters in the provisional budget. This evidence can be interpreted as consistent with a potential negative effect for voters following the relaxation of the rule, only to the extent to which politicians who consistently over-promise public goods are those who care more about reelection rather than social welfare. ${ }^{36}$

In the second panel of Table 8, we look at whether the fiscal (de)stabilization following the relaxation of the DSP is driven by cities with an historical rather than a cyclical deficit in the pre-treatment period, by going as back in time as possible with our data. ${ }^{37}$ Specifically, we classify as municipalities with "historical deficit" those characterized by deficit in all the pre-treatment years, or in all the pre-treatment years but one. One important limitation of this last heterogeneity analysis is that we have limited power for measuring the historical propensity to accumulate debt as we can only rely on four pre-treatment years. ${ }^{38}$ Battaglini and Coate (2008) predict that the costs of restricting fiscal rules will be higher when governments are characterized by cyclical, rather than persistent, deficit. We find that the cities who increase deficit are not those characterized by cyclical deficit, and, if anything, those with more persistent deficit are those who accumulate more debt when unconstrained, although this last result is not statistically significant. ${ }^{39}$

\footnotetext{
${ }^{36}$ Rogoff (1990) argues that electoral incentives might distort fiscal policy because of the distorted incentives to over-provide public good when it is more salient for voters.

${ }^{37}$ Note that we performed an additional robustness check for the five heterogeneity dimensions that we study in this section. Specifically, we checked whether these variables are balanced at the 5,000 threshold. This is indeed what we find, suggesting that our strategy of splitting the sample is keeping the sample balanced in the neighborhood of 5,000 inhabitants as well (results available upon request).

${ }^{38}$ We were able to construct an internally consistent sample of administrative data from the Italian Ministry of the Interior only starting from 1997.

${ }^{39}$ As a final robustness check on our heterogeneity analysis, we repeat the falsification test in 1999 for all the above dimensions but historical deficit (which is constructed using data on the pre-treatment period and thus cannot be used in that context). Specifically, in the Appendix Tables A5, A6, and A7 we implement the above heterogeneity diff-in-disc estimations in the interval 1997-2000, using 1999-2000 as the post-treatment period and 1997-1998 as the pre-treatment period. The fact that no effect and no difference are ever statistically significant means that municipalities around the threshold in different heterogeneity subsamples are not on differential trends before 2001. In other words, the DSP did not bind differently across those subsamples.
} 
On the whole, the results discussed in this section suggest that fiscal restraints are more likely to bind for cities characterized by political failures, and that political economy factors play a first-order role in the process of fiscal adjustment.

\section{Conclusion}

Limiting the increase of public debt is a key policy issue in most economies. Fiscal rules are usually considered one of the potential solutions to public debt growth. In this paper we rely on a novel quasi-experimental design to show that fiscal rules enforced by a national government can be effective in causing a reduction of the accumulation of debt by local governments. Additionally, we are able to investigate the composition of fiscal adjustment and we show that unconstrained cities have lower tax rates and lower revenues following the policy change. We then link our results to existing theories of fiscal adjustment to provide new evidence about the costs and benefits of restraining fiscal policy. We show that deficit bias arises only where many parties seat in the city council, where mayors can run for reelection, where there is a smaller fraction of young citizens, where mayors systematically underprovide the promised public good, and in cities characterized by historical deficit. These results suggest that fiscal restraints can be more effective when political distortions are larger.

We are aware that the enhanced internal validity of our evaluation design comes at the price of lower external validity, as it is always the case in (local) econometric strategies based on policy discontinuities. However, our falsification test shows that mayors who are selected through a different mechanism (that is, a different salary) react in the same way to the introduction of fiscal rules. This suggests that our results can potentially apply to different institutional settings.

Our results raise a number of questions for further research. First, we show that fiscal rules, when accompanied by a proper enforcement mechanism, can be effective also in regulatory environments characterized by serious commitment issues such as the Italian case. Hence, fiscal rules might be useful in far more cases than those suggested by the conventional wisdom, and the optimal design of fiscal rules should take into account political incentives in the enforcement of the rules. Second, our results on the composition of fiscal adjustment

suggest that stabilizing fiscal policy through revenues rather than expenditures might not be 
politically equivalent. A rapidly growing literature in public economics have shown how the salience of tax changes affects behavioral responses (see Chetty, Looney and Kroft, 2009). It is an exciting direction for future research to investigate whether public good provision is subject to similar issues, and whether policy makers can exploit voters' behavioral biases in their favor. ${ }^{40}$

Our last set of empirical results implies that political incentives drive local government responses to exogenously imposed fiscal restraints. Since restricting tax smoothing is the main welfare cost of fiscal restraints identified by the macroeconomic literature, and since mechanisms for smoothing business cycle fluctuations, such as unemployment insurance, are often administered at the national level (as suggested by Gavin and Perotti, 1997), our results suggest that fiscal rules imposed on subnational governments might have limited welfare costs and significant benefits.

\footnotetext{
${ }^{40} \mathrm{~A}$ first attempt along these lines is Bisin, Lizzeri, and Yariv (2011).
} 


\section{References}

Aghion, P., Alesina, A., and F. Trebbi (2004): "Endogenous Political Institutions," Quarterly Journal of Economics, 119, 565- 612.

Aghion, P., and P. Bolton (1990): "Government Domestic Debt and the Risk of Default: a Political-Economic model of the Strategic Role of Debt," in R. Dornbusch and M. Draghi (eds.), Public Debt Management: Theory and History, Cambridge, UK: Cambridge University Press.

Alesina, A., and T. Bayoumi (1996): "The Costs and Benefits of Fiscal Rules: Evidence from U.S. States," NBER Working Paper 5614.

Alesina, A., and R. Perotti (1996): "Fiscal Discipline and the Budget Process," American Economic Review Papers and Proceedings, 86, 401-407.

Alesina, A., and R. Perotti (1999): "Budget Deficits and Budget Institutions," in J. Poterba and J. Von Hagen (eds.), Fiscal Institutions and Fiscal Performance, Chicago, IL: University of Chicago Press.

Alesina, A., and G. Tabellini (1990): "A Positive Theory of Fiscal Deficits and Government Debt," Review of Economic Studies, 57, 403-414.

Alesina, A., Hausmann, R., Hommes, R., and E. Stein (1999): "Budget Institutions and Fiscal Performance in Latin America," Journal of Development Economics, 59, 253273.

Alt, J., and R. Lowry (1994): "Divided Government, Fiscal Institutions, and Budget Deficits: Evidence from the States," American Political Science Review, 88, 811-828.

Angrist, J.D., and A.B. Krueger (1999): "Empirical Strategies in Labor Economics," in: O. Ashenfelter and D. Card (eds.), Handbook of Labor Economics, Vol. 3, Chapter 23, pp. 1277-1366, Elsevier.

Auerbach, A. (2006): "Budget Windows, Sunsets, and Fiscal Control," Journal of Public Economics, 90, 87-100.

Azzimonti, M., Battaglini, M., and S. Coate (2008): "Analyzing the Case for a Balanced Budget Amendment to the U.S. Constitution," mimeo.

Balassone, F., Franco, D., and S. Zotteri (2004): "Fiscal Rules for Sub-national Governments: Lessons from EMU Countries," in G. Kopits (ed.), Rules-Based Fiscal Policy in Emerging Markets: Background, Analysis and Prospects, Palgrave Macmillan. 
Bandiera, O., Prat, A., and T. Valletti (2009): "Active and Passive Waste in Government Spending: Evidence from a Policy Experiment," American Economic Review, 99, 12781308.

Banks, J., and R.K. Sundaram, (1998): "Optimal Retention in Agency Problems," Journal of Economic Theory, 82, 293-323.

Barro, R.J., (1973): "The Control of Politicians: An Economic Model," Public Choice, 14, $19-42$.

Barro, R.J. (1974): "Are Government Bonds Net Wealth?" Journal of Political Economy, 82, 1095-1117

Barro, R.J. (1979): "On the Determination of the Public Debt," Journal of Political Economy, 87, 940-71.

Bassetto, M., and T.J. Sargent (2006): "Politics and Efficiency of Separating Capital and Ordinary Government Budgets," Quarterly Journal of Economics, 121, 1167-1210.

Battaglini, M., and S. Coate (2008): "A Dynamic Theory of Public Spending, Taxation, and Debt," American Economic Review, 98, 201-236.

Bayoumi, T., and B. Eichengreen (1995): "Restraining Yourself: The Implications of Fiscal Rules for Economic Stabilization," IMF Staff Papers, 42, 32-48.

Besley, T., and A. Case (1995): "Does Electoral Accountability Affect Economic Policy Choices? Evidence from Gubernatorial Term Limits," Quarterly Journal of Economics, 110, 769-798.

Besley, T. (2007): Principled Agents? The Political Economy of Good Government, Oxford: Oxford University Press.

Besley, T., and M. Smart (2007): "Fiscal restraints and voter welfare," Journal of Public Economics, 91, 755-773.

Bisin, A., A. Lizzeri, and L. Yariv (2011): "Government Policy with Time Inconsistent Voters," mimeo, New York University.

Bohn, H., and R. Inman (1996): "Balanced-Budget Rules and Public Deficits: Evidence from the U.S. States," Carnegie-Rochester Conference Series on Public Policy, 45, 1376.

Bordignon, M., Nannicini, T., and G. Tabellini (2012): "Moderating Political Extremism: Single Round vs. Runoff Elections under Plurality Rule," mimeo, Bocconi University. 
Braun, M., and M. Tommasi (2004): "Subnational Fiscal Rules: A Game Theoretic Approach," in Kopits, G. (ed.), Rules-Based Fiscal policy in Emerging Markets: Background, Analysis and Prospects, Palgrave Macmillan.

Casaburi, L., and U. Troiano (2012): "Ghost-House Busters: The Electoral Response to a Large Anti Tax Evasion Program," mimeo, Harvard University.

Cellini, S.R., F. Ferreira, and J. Rothstein (2011): "The Value of School Facility Investments: Evidence from a Dynamic Regression Discontinuity Design," Quarterly Journal of Economics, 125, 215-261.

Chetty, R., Looney, A., and K. Kroft (2009): "Salience and Taxation: Theory and Evidence," American Economic Review, 99, 1145-77.

Clemens, J. (2012): "State Fiscal Adjustment During Times of Stress: Possible Causes of the Severity and Composition of Budget Cuts," mimeo.

Clemens, J., and S. Miran (2012): "The Effects of State Budget Cuts on Employment and Income," American Economic Journal: Economic Policy, 4, 46-68.

Debrun, X., L. Moulin, A. Turrini, J. Ayuso-i-Casals, and M.S. Kumar (2008): "Tied to the Mast? National Fiscal Rules in the European Union," Economic Policy, 54, $297-362$.

DellaVigna, S., and E. La Ferrara (2012): "Detecting Illegal Arms Trade," American Economic Journal: Economic Policy, forthcoming.

Dickert-Conlin, S., and T. Elder (2010): "Suburban Legend: School Cutoff Dates and the Timing of Births," Economics of Education Review, 29, 826-841.

Drazen, A. (2002): "Fiscal Rules From a Political Economy Perspective," paper prepared for the IMF-World Bank Conference Rules-Based Fiscal Policy in Emerging Market Economies, Oaxaca, Mexico, February 14-16.

Eichengreen, B., and von Hagen, J. (1996): "Fiscal Policy and Monetary Union: is There a Trade-Off Between Federalism and Budgetary Restrictions?," NBER Working Paper 5517 .

Fatás, A., and I. Mihov (2006): "The Macroeconomic Effects of Fiscal Rules in the US States," Journal of Public Economics, 90, 101-117.

Gagliarducci, S., and T. Nannicini (2012): "Do Better Paid Politicians Perform Better? Disentangling Incentives from Selection," Journal of the European Economic Association, forthcoming. 
Gavin, M., and R. Perotti (1997), "Fiscal policy in Latin America," NBER Macroeconomics Annual 12, 11-72.

Givati, Y., and U. Troiano (2012): "Law, Economics and Culture: Theory and Evidence from Maternity Leave Laws," Journal of Law and Economics, forthcoming.

Glaeser, E. (2012): "Urban Public Finance," in preparation for the Handbook of Public Economics.

Hahn, J., P. Todd, and W. Van der Klaauw (2001): "Identification and Estimation of Treatment Effects with Regression Discontinuity Design," Econometrica, 69, 201-209.

Hallerberg, M., and J. Von Hagen (1999): "Electoral Institutions, Cabinet Negotiations, and Budget Deficits in the EU," in J. Poterba and J. Von Hagen (eds.), Fiscal Institutions and Fiscal Performance, Chicago, IL: University of Chicago Press.

Ichino, A., and G. Maggi (2000): "Work Environment and Individual Background: Explaining Regional Shirking Differentials in a Large Italian Firm," Quarterly Journal of Economics, 15, 1057-90.

Imbens, G., and T. Lemieux (2008): "Regression Discontinuities Designs: A Guide to Practice," Journal of Econometrics, 142, 615-635.

International Monetary Fund (2009): Anchoring Expectations for Sustainable Public Finances, Washington DC.

Kaufmann, D., Kraay, A., and M. Mastruzzi (2010): "The Worldwide Governance Indicators: Methodology and Analytical Issues," World Bank Policy Research Working Paper 5430 .

Knight, B.G. (2000): "Supermajority Voting Requirements for Tax Increases: Evidence from the States," Journal of Public Economics, 76, 41-67.

Kontopoulos, Y., and R. Perotti (1999): "Government Fragmentation and Fiscal Policy Outcomes: Evidence from OECD Countries," in J. Poterba and J. Von Hagen (eds.), Fiscal Institutions and Fiscal Performance, Chicago, IL: University of Chicago Press.

Lemieux, T., and K. Milligan (2008): "Incentive Effects of Social Assistance: A Regression Discontinuity Approach," Journal of Econometrics, 142, 807-828.

Lee, D.S., and T. Lemieux (2010): "Regression Discontinuities Designs in Economics," Journal of Economic Literature, 48, 281-355.

List, J.A., and D.M. Sturm (2006): "How Elections Matter: Theory and Evidence form Environmental Policy," Quarterly Journal of Economics, 121, 1249-1281. 
Lizzeri, A. (1999): "Budget Deficits and Redistributive Politics," Review of Economic Studies, 66, 909-928.

Lucas, R., and N. Stokey (1983): "Optimal Fiscal and Monetary Policy in an Economy without Capital," Journal of Monetary Economics, 12, 55-94.

Maskin, E., and J. Tirole (2004): "The Politician and the Judge: Accountability in Government," American Economic Review, 94, 1034-1054.

McCrary, J. (2008): "Manipulation of the Running Variable in the Regression Discontinuity Design: A Density Test," Journal of Econometrics, 142, 698-714.

Milesi-Ferretti, G.M. (2003): "Good, Bad or Ugly? On the Effects of Fiscal Rules on Creative Accounting," Journal of Public Economics, 88, 377-394.

Nannicini, T., A. Stella, G. Tabellini, and U. Troiano (2012): "Social Capital and Political Accountability," American Economic Journal: Economic Policy, forthcoming.

Olson, M. (1965): The Logic of Collective Action, Cambridge, MA: Harvard University Press.

Persson, T., and G. Tabellini (2000): Political Economics, Cambridge, MA: MIT Press.

Persson, T., and L. Svensson (1989): "Exchange Rate Variability and Asset Trade," Journal of Monetary Economics, 23, 485-509.

Pettersson-Lidbom, P. (2001): "An Empirical Investigation of the Strategic Use of Debt," Journal of Political Economy, 109, 570-584.

Pettersson-Lidbom, P. (2012): "Does the Size of the Legislature Affect the Size of Government: Evidence from Two Natural Experiments," Journal of Public Economics, 96, 269-278.

Poterba, J. (1994): "State Responses to Fiscal Crises: The Effects of Budgetary Institutions and Politics," Journal of Political Economy, 102, 799-821.

Poterba, J. (1996): "Budget Institutions and Fiscal Policy in the U.S. States," American Economic Review Papers and Proceedings, 86, 395-400.

Poterba, J., and J. Von Hagen (eds) (1999): Fiscal Institutions and Fiscal Performance, Chicago, IL: University of Chicago Press.

Rodden, J.A., G.S. Eskeland, and J. Litvack (eds) (2003): Fiscal Decentralization and the Challenge of Hard Budget Constraints, Cambridge, MA: MIT Press.

Rogoff, K. (1990): "Equilibrium Political Budget Cycles," American Economic Review, $80,21-36$. 
Roubini, N., and J. Sachs (1989): "Political and Economic Determinants of Budget Deficits in the Industrial Democracies," European Economic Review, 33, 903-938.

Song, Z., K. Storesletten, and F. Zilibotti (2012): "Rotten Parents and Disciplined Children: A Dynamic Politico-Economic Theory of Public Expenditure and Debt," Econometrica, forthcoming.

Sutherland, D., R. Price, and I. Joumard (2005): "Fiscal Rules for Sub-Central Governments: Design and Impact," OECD Economics Department Working Paper 465.

Tabellini, G., and A. Alesina (1990): "Voting on the Budget Deficit," American Economic Review, 80, 37-49.

Ter-Minassian, T. (2007): "Fiscal Rules for Sub-national Governments: Can They Promote Fiscal Discipline?" OECD Journal on Budgeting, 6(3).

Van der Klaauw, W. (2008): "Regression-Discontinuity Analysis: A Survey of Recent Developments in Economics," Labour, 22, 219-245.

Von Hagen, J. (1991): “A Note on the Empirical Effectiveness of Formal Fiscal Restraints," Journal of Public Economics, 44, 199-210.

Wyplosz, C. (2012), "Fiscal Rules: Theoretical Issues and Historical Experiences," NBER Working Paper 17884.

Yared, P. (2010): "Politicians, Taxes and Debt," The Review of Economic Studies, 77, 806-40. 


\section{Tables and figures}

Table 1: The rules of the Domestic Stability Pact (DSP)

\begin{tabular}{|c|c|c|}
\hline$\overline{\text { Year }}$ & $\begin{array}{l}\text { Target of the } \\
\text { DSP rules }\end{array}$ & $\begin{array}{c}\text { Covered } \\
\text { municipalities }\end{array}$ \\
\hline$\overline{1997}$ & None & All \\
\hline 1998 & None & All \\
\hline 1999 & Fiscal gap: zero growth & All \\
\hline 2000 & Fiscal gap: zero growth & All \\
\hline 2001 & Fiscal gap: $\max 3 \%$ growth & Above 5,000 \\
\hline 2002 & Fiscal gap: $\max 2.5 \%$ growth & Above 5,000 \\
\hline 2003 & Fiscal gap: zero growth & Above 5,000 \\
\hline 2004 & Fiscal gap: zero growth & Above 5,000 \\
\hline
\end{tabular}

Table 2: Legislative thresholds for Italian municipalities, 1997-2004

\begin{tabular}{lccccc}
\hline \hline Population & $\begin{array}{c}\text { Wage of } \\
\text { mayor }\end{array}$ & $\begin{array}{c}\text { Wage of } \\
\text { executive } \\
\text { committee }\end{array}$ & $\begin{array}{c}\text { Size of } \\
\text { executive } \\
\text { committee }\end{array}$ & $\begin{array}{c}\text { Size of } \\
\text { city } \\
\text { council }\end{array}$ & $\begin{array}{c}\text { Electoral } \\
\text { rule }\end{array}$ \\
\hline Below 1,000 & 1,291 & $15 \%$ & 4 & 12 & single \\
$1,000-3,000$ & 1,446 & $20 \%$ & 4 & 12 & single \\
$3,000-5,000$ & 2,169 & $20 \%$ & 4 & 16 & single \\
$5,000-10,000$ & 2,789 & $50 \%$ & 4 & 16 & single \\
$10,000-15,000$ & 3,099 & $55 \%$ & 6 & 20 & single \\
$15,000-30,000$ & 3,099 & $55 \%$ & 6 & 20 & runoff \\
$30,000-50,000$ & 3,460 & $55 \%$ & 6 & 30 & runoff \\
$50,000-100,000$ & 4,132 & $75 \%$ & 6 & 30 & runoff \\
$100,000-250,000$ & 5,010 & $75 \%$ & 10 & 40 & runoff \\
$250,000-500,000$ & 5,784 & $75 \%$ & 12 & 46 & runoff \\
Above 500,000 & 7,798 & $75 \%$ & $14-16$ & $50-60$ & runoff \\
\hline
\end{tabular}

$\overline{\text { Notes. Policies varying at different legislative thresholds in the period 1999-2004. Population is the number of }}$ resident inhabitants as measured by the last available Census. Wage of mayor and Wage of executive committee refer to the monthly gross wage of the mayor and the members of the executive committee, respectively; the latter is expressed as a percentage of the former, which refers to 2000 and is measured in Euros. Size of executive committee is the maximum allowed number of executives appointed by the mayor. Size of city council is the number of seats in the city council. The wage thresholds at 1,000 and 10,000 were introduced in 2000; all of the other thresholds date back to 1960. Since 1993, the Electoral rule for the mayor is plurality with either single round or runoff. 
Table 3: Outcome variables, descriptive statistics

\begin{tabular}{lcc}
\hline \hline & $\begin{array}{c}\text { Municipalities } \\
\text { above 5,000 }\end{array}$ & $\begin{array}{c}\text { Municipalities } \\
\text { below 5,000 }\end{array}$ \\
\hline A. Fiscal discipline & 11.080 & 15.457 \\
Deficit & 170.724 & 208.624 \\
Fiscal gap & & \\
B. Expenditures & 475.312 & 502.181 \\
Current outlays & 438.838 & 508.794 \\
Capital outlays & 29.139 & 30.107 \\
Debt service & & \\
C. Revenues & 194.887 & 175.825 \\
Taxes & 56.601 & 58.938 \\
Fees \& tariffs & 188.783 & 223.274 \\
Central transfers & 491.938 & 567.589 \\
Other revenues & & 0.576 \\
D. Tax instruments & 0.587 & 0.309 \\
Real estate tax rate & 0.309 & 3,330 \\
Income tax surcharge & 2,970 & \\
Obs. & Notes. Municipalities between 3,500 and 7,000 inhabitants; budget years between 1999 \\
and 2004. The average values of per-capita policy outcomes are in 2009 Euros. The real & \\
estate tax rate and the income tax surcharge are in percentage points; the former can vary \\
from 0.4 to 0.7 percent; the latter can vary from 0 to 0.5 percent.
\end{tabular}


Table 4: The effect of relaxing fiscal rules, diff-in-disc estimates

\begin{tabular}{|c|c|c|c|c|}
\hline & $\begin{array}{c}\text { LLR } \\
h=500 \\
\end{array}$ & $\begin{array}{c}\text { LLR } \\
h=750 \\
\end{array}$ & $\begin{array}{c}\text { Spline } \\
\text { poly } 3^{r d}\end{array}$ & $\begin{array}{c}\text { Spline } \\
\text { poly } 4^{t h}\end{array}$ \\
\hline \multicolumn{5}{|l|}{ A. Fiscal discipline } \\
\hline Deficit & $\begin{array}{c}17.358^{* *} \\
(8.377)\end{array}$ & $\begin{array}{c}19.234^{* * *} \\
(6.256)\end{array}$ & $\begin{array}{c}21.449^{* *} \\
(9.485)\end{array}$ & $\begin{array}{c}25.109^{* *} \\
(12.756)\end{array}$ \\
\hline Fiscal gap & $\begin{array}{l}61.748^{*} \\
(32.584) \\
\end{array}$ & $\begin{array}{c}57.839^{* *} \\
(25.016) \\
\end{array}$ & $\begin{array}{c}102.202^{* * *} \\
(38.463)\end{array}$ & $\begin{array}{c}108.128^{* *} \\
(48.372) \\
\end{array}$ \\
\hline \multicolumn{5}{|l|}{ B. Expenditures } \\
\hline Current outlays & $\begin{array}{l}-52.570 \\
(55.367)\end{array}$ & $\begin{array}{c}-4.208 \\
(36.093)\end{array}$ & $\begin{array}{c}-32.366 \\
(55.631)\end{array}$ & $\begin{array}{c}-60.520 \\
(77.460)\end{array}$ \\
\hline Capital outlays & $\begin{array}{c}42.331 \\
(87.304)\end{array}$ & $\begin{array}{c}44.482 \\
(63.528)\end{array}$ & $\begin{array}{c}91.321 \\
(103.145)\end{array}$ & $\begin{array}{c}202.679 \\
(140.024)\end{array}$ \\
\hline Debt service & $\begin{array}{l}-1.851 \\
(6.895) \\
\end{array}$ & $\begin{array}{l}-1.593 \\
(4.176) \\
\end{array}$ & $\begin{array}{l}-2.338 \\
(6.631) \\
\end{array}$ & $\begin{array}{l}-2.375 \\
(9.675) \\
\end{array}$ \\
\hline \multicolumn{5}{|l|}{ C. Revenues } \\
\hline Taxes & $\begin{array}{c}-45.248^{*} \\
(25.980)\end{array}$ & $\begin{array}{c}-36.779^{*} \\
(19.185)\end{array}$ & $\begin{array}{c}-57.028^{* *} \\
(27.193)\end{array}$ & $\begin{array}{c}-85.077^{* *} \\
(35.162)\end{array}$ \\
\hline Fees \& tariffs & $\begin{array}{c}-3.359 \\
(10.214)\end{array}$ & $\begin{array}{c}0.100 \\
(7.416)\end{array}$ & $\begin{array}{c}1.173 \\
(10.601)\end{array}$ & $\begin{array}{c}-4.051 \\
(13.910)\end{array}$ \\
\hline Central transfers & $\begin{array}{c}42.539 \\
(30.020)\end{array}$ & $\begin{array}{c}37.012 \\
(23.104)\end{array}$ & $\begin{array}{c}78.414^{* *} \\
(35.334)\end{array}$ & $\begin{array}{l}80.644^{*} \\
(43.517)\end{array}$ \\
\hline Other revenues & $\begin{array}{c}-23.380 \\
(108.275) \\
\end{array}$ & $\begin{array}{c}19.114 \\
(72.838) \\
\end{array}$ & $\begin{array}{c}12.608 \\
(118.470) \\
\end{array}$ & $\begin{array}{c}123.159 \\
(165.666) \\
\end{array}$ \\
\hline \multicolumn{5}{|l|}{ D. Tax instruments } \\
\hline Real estate tax rate & $\begin{array}{c}-0.040^{*} \\
(0.024)\end{array}$ & $\begin{array}{l}-0.028 \\
(0.018)\end{array}$ & $\begin{array}{c}-0.056^{* *} \\
(0.026)\end{array}$ & $\begin{array}{c}-0.060^{*} \\
(0.033)\end{array}$ \\
\hline Income tax surcharge & $\begin{array}{c}-0.036 \\
(0.036) \\
\end{array}$ & $\begin{array}{c}-0.057^{* *} \\
(0.029) \\
\end{array}$ & $\begin{array}{l}-0.058 \\
(0.041) \\
\end{array}$ & $\begin{array}{c}-0.111^{* *} \\
(0.051) \\
\end{array}$ \\
\hline Obs. & 2,080 & 3,068 & 6,300 & 6,300 \\
\hline
\end{tabular}


Table 5: Falsification test in 1999

\begin{tabular}{|c|c|c|c|c|}
\hline & $\begin{array}{c}\text { LLR } \\
h=500\end{array}$ & $\begin{array}{c}\text { LLR } \\
h=750\end{array}$ & $\begin{array}{c}\text { Spline } \\
\text { poly } 3^{r d}\end{array}$ & $\begin{array}{c}\text { Spline } \\
\text { poly } 4^{t h}\end{array}$ \\
\hline \multicolumn{5}{|l|}{ A. Fiscal discipline } \\
\hline Deficit & $\begin{array}{c}1.303 \\
(7.604)\end{array}$ & $\begin{array}{l}-4.735 \\
(7.402)\end{array}$ & $\begin{array}{c}0.942 \\
(8.997)\end{array}$ & $\begin{array}{c}-1.520 \\
(10.673)\end{array}$ \\
\hline Fiscal gap & $\begin{array}{c}2.425 \\
(11.158)\end{array}$ & $\begin{array}{c}5.151 \\
(8.836)\end{array}$ & $\begin{array}{c}12.440 \\
(11.882)\end{array}$ & $\begin{array}{c}-2.693 \\
(15.294)\end{array}$ \\
\hline \multicolumn{5}{|l|}{ B. Expenditures } \\
\hline Current outlays & $\begin{array}{l}-2.027 \\
(9.365)\end{array}$ & $\begin{array}{l}-8.305 \\
(8.724)\end{array}$ & $\begin{array}{l}-11.384 \\
(10.605)\end{array}$ & $\begin{array}{c}-6.307 \\
(11.584)\end{array}$ \\
\hline Capital outlays & $\begin{array}{c}0.528 \\
(52.206)\end{array}$ & $\begin{array}{l}-35.770 \\
(45.759)\end{array}$ & $\begin{array}{l}-13.273 \\
(59.126)\end{array}$ & $\begin{array}{l}-93.598 \\
(98.401)\end{array}$ \\
\hline Debt service & $\begin{array}{l}-0.220 \\
(1.239)\end{array}$ & $\begin{array}{c}-0.347 \\
(1.058)\end{array}$ & $\begin{array}{c}-0.786 \\
(1.278)\end{array}$ & $\begin{array}{c}0.368 \\
(1.591)\end{array}$ \\
\hline \multicolumn{5}{|l|}{ C. Revenues } \\
\hline Taxes & $\begin{array}{l}-1.300 \\
(4.024)\end{array}$ & $\begin{array}{c}1.905 \\
(3.668)\end{array}$ & $\begin{array}{l}-3.411 \\
(4.270)\end{array}$ & $\begin{array}{c}-2.401 \\
(4.923)\end{array}$ \\
\hline Fees \& tariffs & $\begin{array}{c}3.168 \\
(3.267)\end{array}$ & $\begin{array}{c}2.681 \\
(3.222)\end{array}$ & $\begin{array}{l}-0.654 \\
(3.428)\end{array}$ & $\begin{array}{c}0.241 \\
(3.490)\end{array}$ \\
\hline Central transfers & $\begin{array}{l}-2.270 \\
(6.449)\end{array}$ & $\begin{array}{c}1.755 \\
(5.415)\end{array}$ & $\begin{array}{l}-3.298 \\
(7.187)\end{array}$ & $\begin{array}{r}-11.149 \\
(9.013)\end{array}$ \\
\hline Other revenues & $\begin{array}{c}34.986 \\
(38.066)\end{array}$ & $\begin{array}{l}-11.711 \\
(32.788)\end{array}$ & $\begin{array}{c}27.041 \\
(43.639)\end{array}$ & $\begin{array}{c}-62.725 \\
(86.491)\end{array}$ \\
\hline D. Tax instruments & & & & \\
\hline Real estate tax rate & $\begin{array}{c}0.005 \\
(0.009) \\
\end{array}$ & $\begin{array}{c}0.009 \\
(0.007) \\
\end{array}$ & $\begin{array}{c}0.002 \\
(0.009) \\
\end{array}$ & $\begin{array}{c}0.002 \\
(0.011)\end{array}$ \\
\hline Obs. & 1,260 & 1,848 & 4,176 & 4,176 \\
\hline
\end{tabular}

Notes. Municipalities between 3,500 and 7,000 inhabitants; budget years between 1997 and 2001. Diff-in-disc estimates of the (false) impact of introducing fiscal rules on policy outcomes below 5,000 after 1999 (when no discontinuity was introduced by the DSP; see Table 1). Estimation methods: Local Linear Regression (LLR) with bandwidth $h=500$ or $h=750$, as in equation (4); spline polynomial approximation with $3^{r d}$-order or $4^{t h}$-order polynomial, as in equation (5). All policy outcomes are per capita and in 2009 Euros. The real estate tax rate is in percentage points (the income tax surcharge is not available for this test because it was introduced in 1999). Fiscal gap, Current outlays, Capital outlays, and Debt service are not available in 1997; for these variables the observations in the four estimations, respectively, are: $945 ; 1,389 ; 3,135 ; 3,135$. Robust standard errors clustered at the municipality level are in parentheses. Significance at the $10 \%$ level is represented by $*$, at the $5 \%$ level by ${ }^{* *}$, and at the $1 \%$ level by $* * *$. 
Table 6: The political economy of deficit bias, part I

\begin{tabular}{|c|c|c|c|c|}
\hline & $\begin{array}{c}\text { LLR } \\
h=500\end{array}$ & $\begin{array}{c}\text { LLR } \\
h=750\end{array}$ & $\begin{array}{c}\text { Spline } \\
\text { poly } 3^{r d}\end{array}$ & $\begin{array}{c}\text { Spline } \\
\text { poly } 4^{t h}\end{array}$ \\
\hline & \multicolumn{4}{|c|}{ With two parties or less: } \\
\hline Deficit & $\begin{array}{c}0.720 \\
(9.511)\end{array}$ & $\begin{array}{c}2.753 \\
(7.650)\end{array}$ & $\begin{array}{c}3.278 \\
(10.369)\end{array}$ & $\begin{array}{c}2.993 \\
(12.379)\end{array}$ \\
\hline \multirow[t]{2}{*}{ Obs. } & 1,187 & 1,721 & 3,584 & 3,584 \\
\hline & \multicolumn{4}{|c|}{ With more than two parties: } \\
\hline Deficit & $\begin{array}{c}44.096^{* * *} \\
(15.429)\end{array}$ & $\begin{array}{c}42.958^{* * *} \\
(12.082)\end{array}$ & $\begin{array}{c}50.869^{* * * *} \\
(19.446)\end{array}$ & $\begin{array}{l}69.627^{* *} \\
(27.413)\end{array}$ \\
\hline Obs. & 893 & 1,347 & 2,716 & 2,716 \\
\hline $\begin{array}{l}\text { Difference between } \\
\text { the two subsamples }\end{array}$ & 43.376 & 40.205 & 47.591 & 66.634 \\
\hline $\begin{array}{l}\text { Wald test p-value } \\
\text { without covariates }\end{array}$ & 0.034 & 0.015 & 0.022 & 0.044 \\
\hline \multicolumn{4}{|l|}{ Wald test p-value } & 0.049 \\
\hline & \multicolumn{4}{|c|}{ With binding term limit: } \\
\hline Deficit & $\begin{array}{c}0.967 \\
(8.463)\end{array}$ & $\begin{array}{l}7.861 \\
(6.957)\end{array}$ & $\begin{array}{c}4.017 \\
(9.599)\end{array}$ & $\begin{array}{c}5.598 \\
(12.083)\end{array}$ \\
\hline \multirow[t]{2}{*}{ Obs. } & 920 & 1,375 & 2,780 & 2,780 \\
\hline & \multicolumn{4}{|c|}{ Without binding term limit: } \\
\hline Deficit & $\begin{array}{l}29.531^{* *} \\
(13.120)\end{array}$ & $\begin{array}{c}27.189^{* * *} \\
(9.428)\end{array}$ & $\begin{array}{c}33.047^{* *} \\
(14.471)\end{array}$ & $\begin{array}{l}36.640^{*} \\
(20.332)\end{array}$ \\
\hline Obs. & 1,160 & 1,693 & 3,520 & 3,520 \\
\hline $\begin{array}{l}\text { Difference between } \\
\text { the two subsamples }\end{array}$ & 28.564 & 19.328 & 29.030 & 31.042 \\
\hline $\begin{array}{l}\text { Wald test p-value } \\
\text { without covariates }\end{array}$ & 0.071 & 0.088 & 0.090 & 0.189 \\
\hline $\begin{array}{l}\text { Wald test p-value } \\
\text { with covariates }\end{array}$ & 0.097 & 0.064 & 0.096 & 0.227 \\
\hline $\begin{array}{l}\text { Notes. Municipalities } \\
\text { of the impact of relaxi } \\
\text { vs. below median numb } \\
\text { (LLR) with bandwidth } \\
4^{t h} \text {-order polynomial, } \\
\text { statistically different in } \\
\text { statistically different in } \\
\text { and appropriate covari } \\
\text { in the North. All varia } \\
\text { are in parentheses. Sign }\end{array}$ & $\begin{array}{l}500 \text { and } 7,000 \\
\text { ules on fiscal } \\
\text { les; binding vs } \\
\text { or } h=750 \text {, } \\
\text { ion (5). The } \\
\text { ubsamples. T } \\
\text { ubsamples als } \\
\text { as: average ta } \\
\text { r capita and i } \\
\text { the } 10 \% \text { leve }\end{array}$ & $\begin{array}{l}\text { ts; budget yea } \\
\text { below 5,000 a } \\
\text { ding term limi } \\
\text { lation (4); spl } \\
\text { p-value witho } \\
\text { est p-value wi } \\
\text { ng for a full se } \\
\text { me; mayor's y } \\
\text { ros. Robust s }\end{array}$ & $\begin{array}{l}1999 \text { and } 200 \\
\text { different su } \\
\text { ion methods: } \\
\text { nial approxin } \\
s \text { evaluates w } \\
s \text { evaluates w } \\
\text { tions between } \\
\text { oling; and wh }\end{array}$ & $\begin{array}{l}\text { lisc estimates } \\
\text { hat is, above } \\
\text { ar Regression } \\
3^{r d} \text {-order or } \\
\text { estimates are } \\
\text { estimates are } \\
\text { specifications } \\
\text { iunicipality is } \\
\text { icipality level } \\
\text { evel by } * * * \text {. }\end{array}$ \\
\hline
\end{tabular}


Table 7: The political economy of deficit bias, part II

\begin{tabular}{|c|c|c|c|c|}
\hline & $\begin{array}{c}\text { LLR } \\
h=500\end{array}$ & $\begin{array}{c}\text { LLR } \\
h=750\end{array}$ & $\begin{array}{c}\text { Spline } \\
\text { poly } 3^{r d}\end{array}$ & $\begin{array}{c}\text { Spline } \\
\text { poly } 4^{t h}\end{array}$ \\
\hline & \multicolumn{4}{|c|}{ Young cohorts above median: } \\
\hline \multirow[t]{2}{*}{ Deficit } & 0.887 & 8.110 & 7.094 & 4.151 \\
\hline & $(10.509)$ & $(7.753)$ & $(11.067)$ & $(14.635)$ \\
\hline \multirow[t]{2}{*}{ Obs. } & 1,059 & 1,561 & 3,224 & 3,244 \\
\hline & \multicolumn{4}{|c|}{ Young cohorts below median: } \\
\hline Deficit & $35.523^{* * *}$ & $31.244^{* * *}$ & $36.913^{* * *}$ & $49.481^{* * *}$ \\
\hline & $(12.010)$ & $(9.390)$ & $(14.255)$ & $(18.795)$ \\
\hline Obs. & 1,021 & 1,507 & 3,076 & 3,076 \\
\hline \multicolumn{5}{|l|}{ Difference between } \\
\hline the two subsamples & 34.636 & 23.134 & 29.819 & 45.330 \\
\hline $\begin{array}{l}\text { Wald test p-value } \\
\text { without covariates }\end{array}$ & 0.024 & 0.050 & 0.082 & 0.041 \\
\hline $\begin{array}{l}\text { Wald test p-value } \\
\text { with covariates }\end{array}$ & 0.052 & 0.068 & 0.156 & 0.048 \\
\hline
\end{tabular}

Notes. Municipalities between 3,500 and 7,000 inhabitants; budget years between 1999 and 2004. Diff-in-disc estimates of the impact of relaxing fiscal rules on fiscal discipline below 5,000 after 2001 in different subsamples (that is, above vs. below median percentage of young cohorts). Estimation methods: Local Linear Regression (LLR) with bandwidth $h=500$ or $h=750$, as in equation (4); spline polynomial approximation with $3^{r d}$-order or $4^{t h}$-order polynomial, as in equation (5). The Wald test p-value without covariates evaluates whether the estimates are statistically different in the two subsamples. The Wald test p-value with covariates evaluates whether the estimates are statistically different in the two subsamples also controlling for a full set of interactions between the above specifications and appropriate covariates, such as: average taxable income; mayor's years of schooling; and whether the municipality is in the North. All variables are per capita and in 2009 Euros. Robust standard errors clustered at the municipality level are in parentheses. Significance at the $10 \%$ level is represented by $*$, at the $5 \%$ level by ${ }^{* *}$, and at the $1 \%$ level by $* * *$. 
Table 8: Fiscal restraints and budget management

\begin{tabular}{|c|c|c|c|c|}
\hline & $\begin{array}{c}\text { LLR } \\
h=500\end{array}$ & $\begin{array}{c}\text { LLR } \\
h=750\end{array}$ & $\begin{array}{c}\text { Spline } \\
\text { poly } 3^{r d}\end{array}$ & $\begin{array}{c}\text { Spline } \\
\text { poly } 4^{t h}\end{array}$ \\
\hline & \multicolumn{4}{|c|}{ Speed of public good provision above median: } \\
\hline \multirow[t]{2}{*}{ Deficit } & -0.851 & 7.946 & 4.433 & 3.717 \\
\hline & $(11.291)$ & $(7.880)$ & $(11.602)$ & $(16.051)$ \\
\hline \multirow[t]{2}{*}{ Obs. } & 1,022 & 1,492 & 3,153 & 3,153 \\
\hline & \multicolumn{4}{|c|}{ Speed of public good provision below median: } \\
\hline \multirow[t]{2}{*}{ Deficit } & $35.082^{* * *}$ & $29.395^{* * *}$ & $38.184^{* *}$ & $47.452^{* *}$ \\
\hline & $(11.995)$ & $(9.498)$ & $(14.811)$ & $(20.275)$ \\
\hline Obs. & 1,058 & 1,576 & 3,147 & 3,147 \\
\hline \multicolumn{5}{|l|}{ Difference between } \\
\hline the two subsamples & 35.932 & 21.449 & 33.751 & 43.735 \\
\hline Wald test p-value & 0.025 & 0.075 & 0.065 & 0.086 \\
\hline \multicolumn{5}{|l|}{ Wald test p-value } \\
\hline \multirow[t]{2}{*}{ with covariates } & 0.029 & 0.109 & 0.063 & 0.057 \\
\hline & \multicolumn{4}{|c|}{ Historical deficit: } \\
\hline \multirow[t]{2}{*}{ Deficit } & $25.023^{* * *}$ & $19.831^{* * *}$ & $26.365^{* * *}$ & $26.192^{* * *}$ \\
\hline & $(6.599)$ & $(6.300)$ & $(7.913)$ & $(9.260)$ \\
\hline \multirow[t]{2}{*}{ Obs. } & 1,536 & 2,256 & 4,648 & 4,648 \\
\hline & \multicolumn{4}{|c|}{ No historical deficit: } \\
\hline \multirow[t]{2}{*}{ Deficit } & 6.481 & 4.279 & 10.843 & 10.197 \\
\hline & $(17.967)$ & $(13.156)$ & $(20.978)$ & $(30.104)$ \\
\hline Obs. & 912 & 1,332 & 2,712 & 2,712 \\
\hline \multicolumn{5}{|l|}{ Difference between } \\
\hline the two subsamples & 18.542 & 15.552 & 15.522 & 15.995 \\
\hline $\begin{array}{l}\text { Wald test p-value } \\
\text { without covariates }\end{array}$ & 0.332 & 0.286 & 0.488 & 0.611 \\
\hline $\begin{array}{l}\text { Wald test p-value } \\
\text { with covariates }\end{array}$ & 0.264 & 0.342 & 0.557 & 0.453 \\
\hline
\end{tabular}

$\overline{\text { Notes. Municipalities between 3,500 and 7,000 inhabitants; between } 1999 \text { and 2004. Diff-in-disc estimates of the impact of }}$ relaxing fiscal rules on fiscal discipline below 5,000 after 2001 in different subsamples (that is, above vs. below median speed of public good provision; historical vs. no historical deficit). Municipalities with historical deficit are those characterized by deficit in all the pre-treatment years since 1997, or in all the pre-treatment years but one. Estimation methods: Local Linear Regression (LLR) with bandwidth $h=500$ or $h=750$, as in equation (4); spline polynomial approximation with $3^{r d}$-order or $4^{t h}$-order polynomial, as in equation (5). The Wald test p-value without covariates evaluates whether the estimates are statistically different in the two subsamples. The Wald test p-value with covariates evaluates whether the estimates are statistically different in the two subsamples also controlling for a full set of interactions between the above specifications and appropriate covariates, such as: average taxable income; mayor's years of schooling; and whether the municipality is in the North. All variables are per capita and in 2009 Euros. Robust standard errors clustered at the municipality level are in parentheses. Significance at the $10 \%$ level is represented by $*$, at the $5 \%$ level by $* *$, and at the $1 \%$ level by $* * *$. 


\section{Figure 1: Difference-in-discontinuities for deficit}
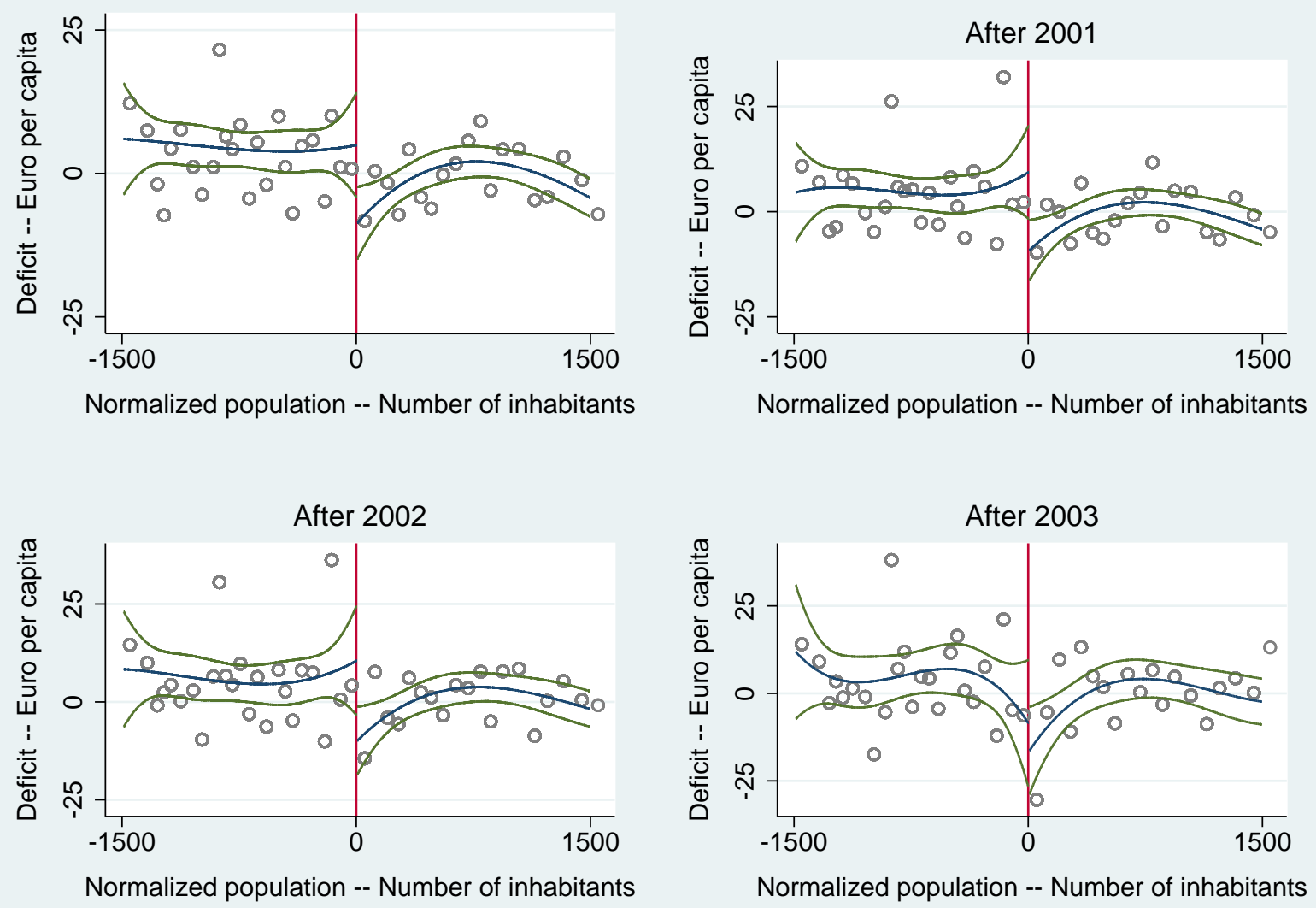

Notes. Vertical axis: difference of each post-2001 (i.e. 2001, 2002, 2003, and 2004) outcome value and each pre-2001 (i.e. 1999 and $2000)$ outcome value. Horizontal axis: actual population size minus 5,000. The central line is a spline $3^{r d}$-order polynomial fit; the lateral lines represent the $95 \%$ confidence interval. Scatter points are averaged over intervals of 50 inhabitants. 
Figure 2: Difference-in-discontinuities for fiscal gap

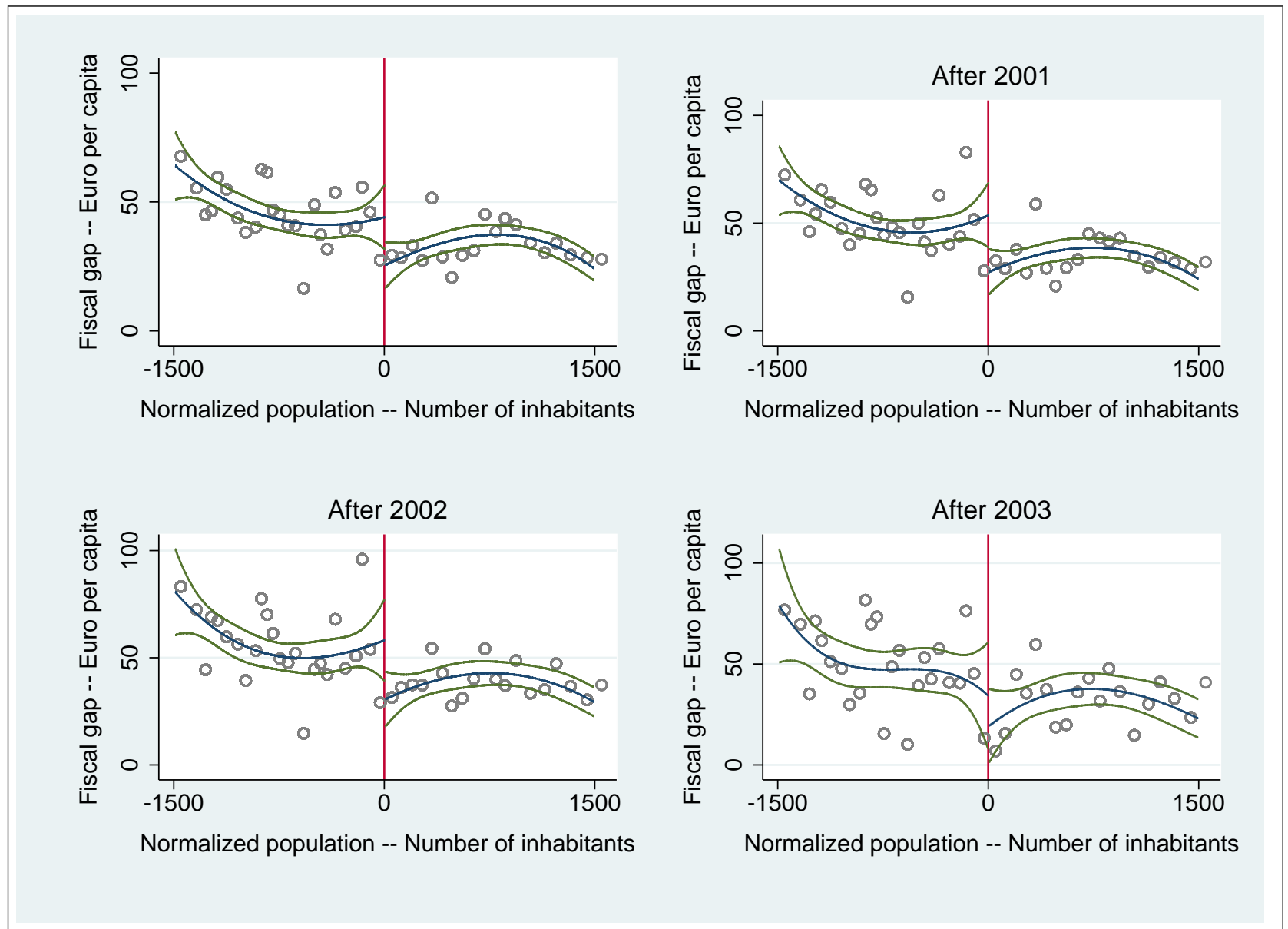

Notes. Vertical axis: difference of each post-2001 (i.e. 2001, 2002, 2003, and 2004) outcome value and each pre-2001 (i.e. 1999 and 2000 ) outcome value. Horizontal axis: actual population size minus 5,000. The central line is a spline $3^{\text {rd }}$-order polynomial fit; the lateral lines represent the $95 \%$ confidence interval. Scatter points are averaged over intervals of 50 inhabitants. 


\section{Figure 3: Difference-in-discontinuities for policy outcomes and tax instruments}

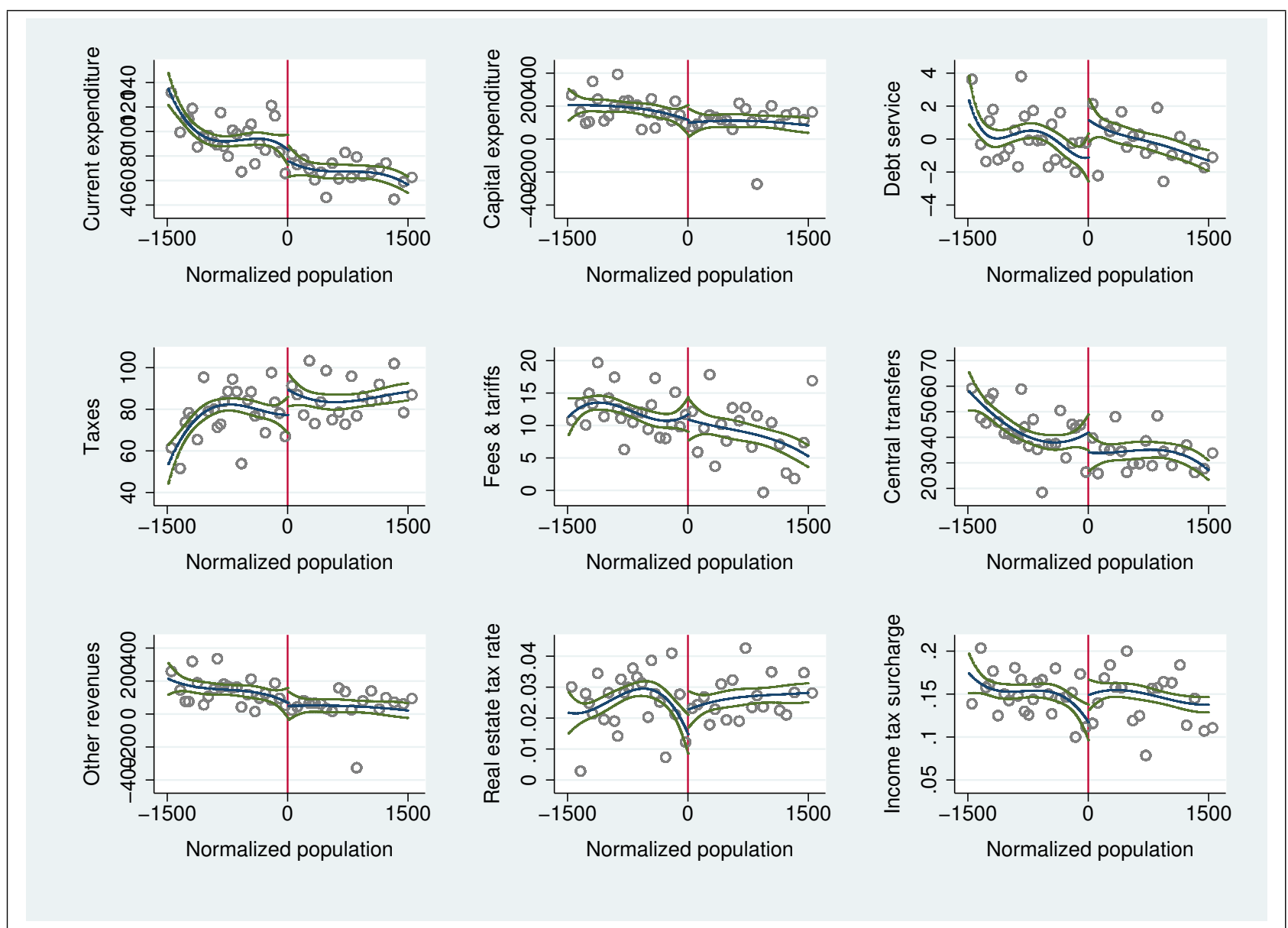

Notes. Vertical axis: difference of each post-2001 (i.e. 2001, 2002, 2003, and 2004) outcome value and each pre-2001 (i.e. 1999 and $2000)$ outcome value. Horizontal axis: actual population size minus 5,000. The central line is a spline $3^{r d}$-order polynomial fit; the lateral lines represent the $95 \%$ confidence interval. Scatter points are averaged over intervals of 50 inhabitants. 


\section{Appendix (not for publication)}

This Appendix provides additional information and robustness checks, which are also discussed in the paper. In particular, we describe the characteristics and sources of the variables we use (Table A1), and we present further robustness checks:

- diff-in-disc estimates with covariates (Table A2);

- balance tests of time-invariant municipal characteristics (Table A3);

- diff-in-disc estimates on potentially endogenous variables (Table A4);

- falsification tests for the heterogeneity analysis (Table A5, Table A6, and Table A7);

- test of the continuity of the density at 5,000 in the 1991 Census, in the 2001 Census, and with respect to the difference between the two Censuses (Figure A1);

- placebo tests based on permutation methods (Figure A2 and Figure A3). 


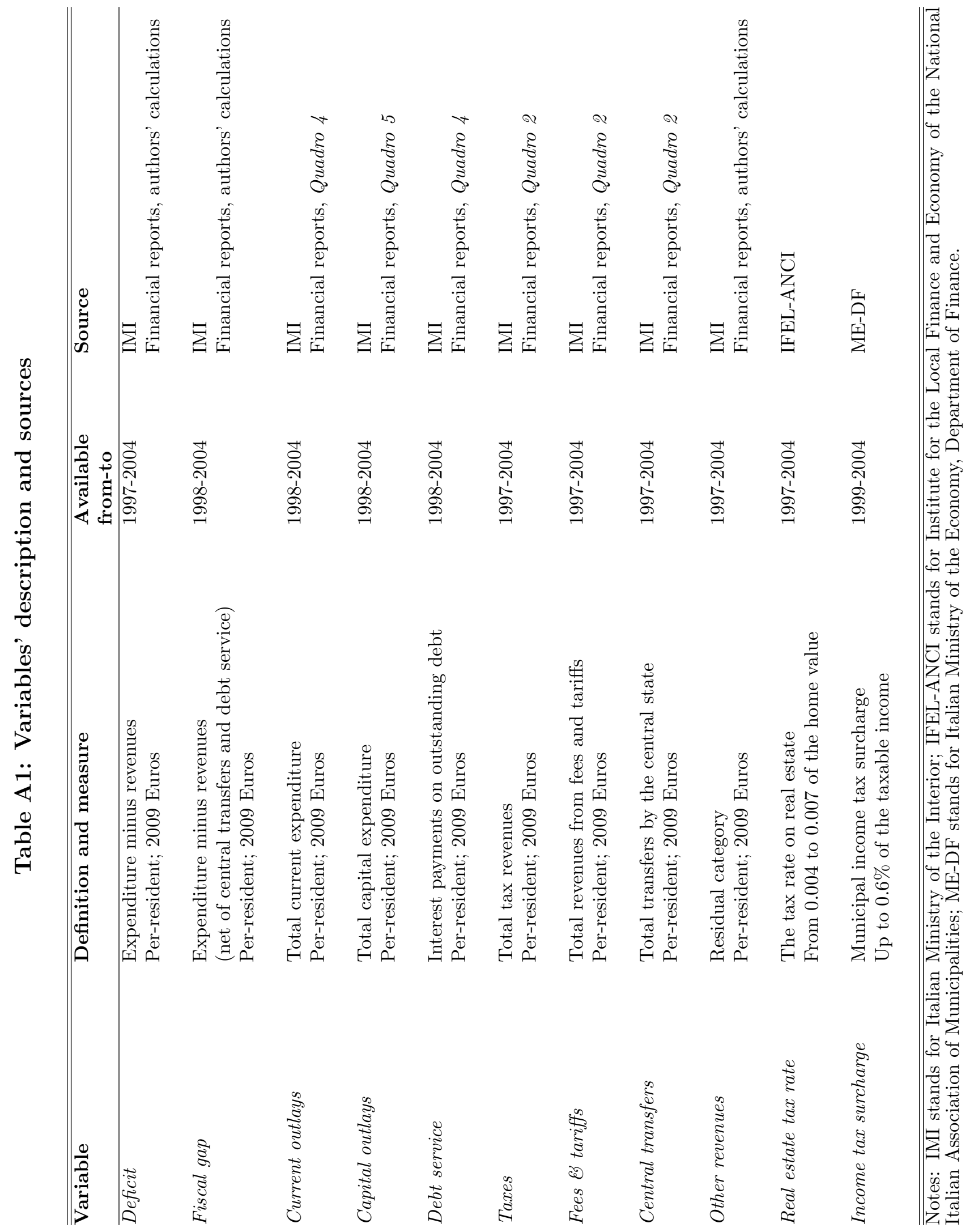




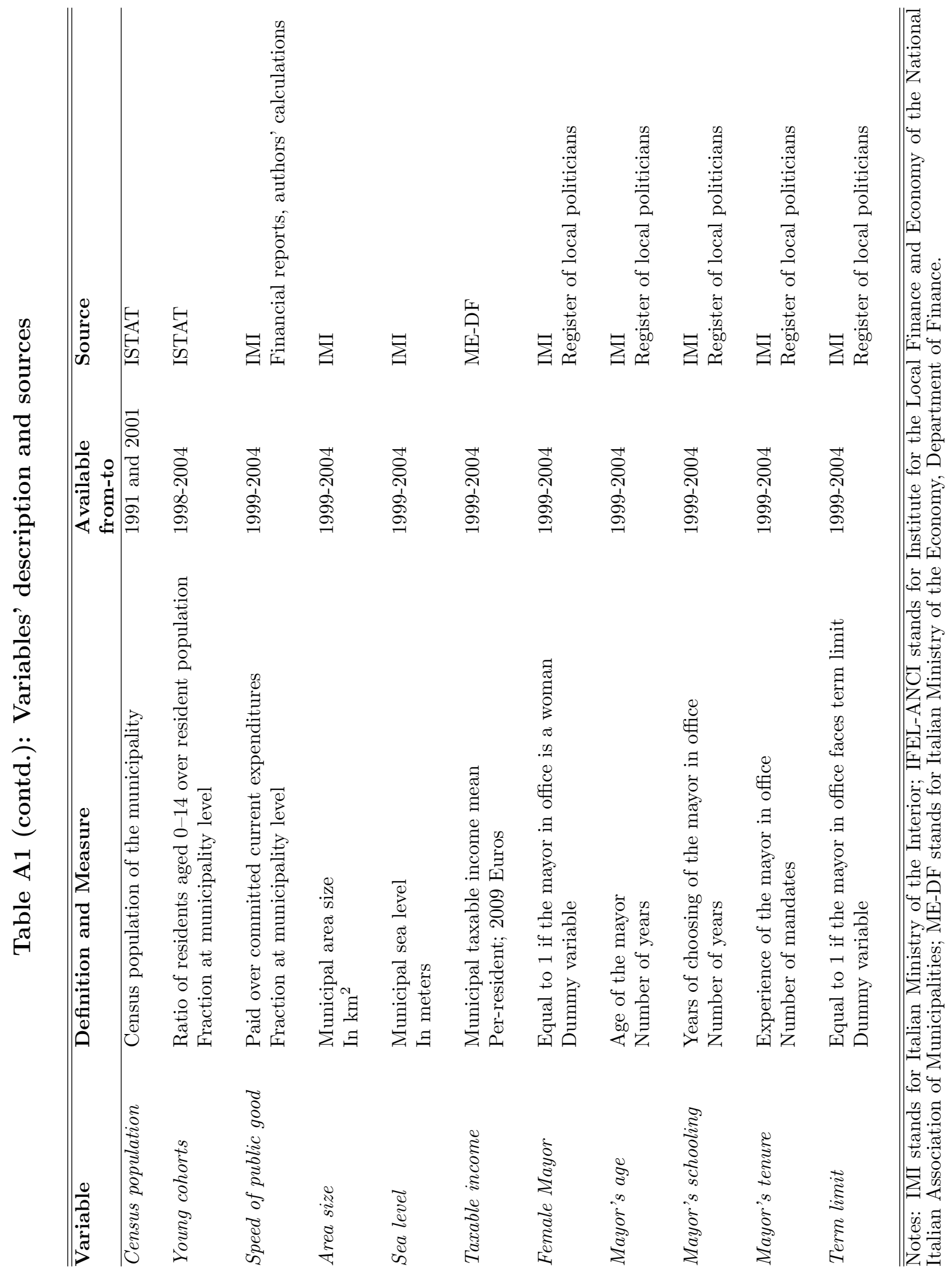


Table A2: The effect of relaxing fiscal rules, estimates with covariates

\begin{tabular}{|c|c|c|c|c|}
\hline & $\begin{array}{c}\text { LLR } \\
h=500\end{array}$ & $\begin{array}{c}\text { LLR } \\
h=750\end{array}$ & $\begin{array}{c}\text { Spline } \\
\text { poly } 3^{r d}\end{array}$ & $\begin{array}{c}\text { Spline } \\
\text { poly } 4^{t h}\end{array}$ \\
\hline \multicolumn{5}{|l|}{ A. Fiscal discipline } \\
\hline Deficit & $\begin{array}{c}16.085^{* *} \\
(8.082)\end{array}$ & $\begin{array}{c}19.265^{* * *} \\
(6.208)\end{array}$ & $\begin{array}{c}21.094^{* *} \\
(9.283)\end{array}$ & $\begin{array}{l}23.396^{*} \\
(12.579)\end{array}$ \\
\hline Fiscal gap & $\begin{array}{c}70.704^{* * *} \\
(26.436)\end{array}$ & $\begin{array}{c}56.734^{* * *} \\
(20.049)\end{array}$ & $\begin{array}{c}96.748^{* * *} \\
(32.595)\end{array}$ & $\begin{array}{c}118.962^{* * * *} \\
(41.570)\end{array}$ \\
\hline \multicolumn{5}{|l|}{ B. Expenditures } \\
\hline Current outlays & $\begin{array}{c}-60.558 \\
(49.861)\end{array}$ & $\begin{array}{l}-13.958 \\
(32.864)\end{array}$ & $\begin{array}{l}-44.755 \\
(50.871)\end{array}$ & $\begin{array}{c}-68.705 \\
(72.117)\end{array}$ \\
\hline Capital outlays & $\begin{array}{c}54.450 \\
(76.831)\end{array}$ & $\begin{array}{c}44.429 \\
(59.520)\end{array}$ & $\begin{array}{c}102.644 \\
(101.934)\end{array}$ & $\begin{array}{l}224.342^{*} \\
(136.181)\end{array}$ \\
\hline Debt service & $\begin{array}{l}-1.962 \\
(6.107) \\
\end{array}$ & $\begin{array}{l}-1.077 \\
(3.833) \\
\end{array}$ & $\begin{array}{l}-1.962 \\
(6.145) \\
\end{array}$ & $\begin{array}{l}-2.298 \\
(9.151) \\
\end{array}$ \\
\hline \multicolumn{5}{|l|}{ C. Revenues } \\
\hline Taxes & $\begin{array}{c}-56.638^{* *} \\
(23.920)\end{array}$ & $\begin{array}{c}-40.683^{* *} \\
(17.221)\end{array}$ & $\begin{array}{c}-56.863^{* *} \\
(24.024)\end{array}$ & $\begin{array}{c}-93.975^{* * *} \\
(30.751)\end{array}$ \\
\hline Fees \& tariffs & $\begin{array}{l}-6.989 \\
(9.676)\end{array}$ & $\begin{array}{l}-2.700 \\
(7.028)\end{array}$ & $\begin{array}{c}-2.992 \\
(10.049)\end{array}$ & $\begin{array}{l}-10.241 \\
(13.341)\end{array}$ \\
\hline Central transfers & $\begin{array}{c}52.658^{* *} \\
(23.251)\end{array}$ & $\begin{array}{c}36.392^{* *} \\
(17.730)\end{array}$ & $\begin{array}{c}73.692^{* *} \\
(29.036)\end{array}$ & $\begin{array}{c}93.268^{* *} \\
(36.275)\end{array}$ \\
\hline Other revenues & $\begin{array}{l}-13.186 \\
(92.763) \\
\end{array}$ & $\begin{array}{c}17.120 \\
(67.138) \\
\end{array}$ & $\begin{array}{c}20.996 \\
(112.937) \\
\end{array}$ & $\begin{array}{c}140.891 \\
(155.552) \\
\end{array}$ \\
\hline \multicolumn{5}{|l|}{ D. Tax instruments } \\
\hline Real estate tax rate & $\begin{array}{c}-0.043^{*} \\
(0.024)\end{array}$ & $\begin{array}{c}-0.030^{*} \\
(0.018)\end{array}$ & $\begin{array}{c}-0.058^{* *} \\
(0.026)\end{array}$ & $\begin{array}{c}-0.060^{*} \\
(0.033)\end{array}$ \\
\hline Income tax surcharge & $\begin{array}{l}-0.027 \\
(0.037) \\
\end{array}$ & $\begin{array}{c}-0.053^{*} \\
(0.029) \\
\end{array}$ & $\begin{array}{c}-0.051 \\
(0.042) \\
\end{array}$ & $\begin{array}{c}-0.103^{* *} \\
(0.052) \\
\end{array}$ \\
\hline Obs. & 2,080 & 3,068 & 6,300 & 6,300 \\
\hline
\end{tabular}

$\overline{\text { Notes. Municipalities between 3,500 and 7,000 inhabitants; budget years between } 1999 \text { and 2004. Diff-in-disc estimates of the }}$ impact of relaxing fiscal rules on policy outcomes and tax instruments below 5,000 after 2001. Specifications augmented by controlling for covariates: yearly dummies, macro areas dummies (i.e. North West, North East, South), area size (in $\mathrm{km}^{2}$ ), and sea level (in meters). Estimation methods: Local Linear Regression (LLR) with bandwidth $h=500$ or $h=750$, as in equation (4); spline polynomial approximation with $3^{\text {rd }}$-order or $4^{\text {th }}$-order polynomial, as in equation (5). All policy outcomes are per capita and in 2009 Euros. Tax instruments are in percentage points. Robust standard errors clustered at the municipality level are in parentheses. Significance at the $10 \%$ level is represented by *, at the $5 \%$ level by **, and at the $1 \%$ level by ***. 
Table A3: Balance tests of time-invariant characteristics

\begin{tabular}{|c|c|c|c|c|}
\hline & $\begin{array}{c}\text { LLR } \\
h=500\end{array}$ & $\begin{array}{c}\text { LLR } \\
h=750\end{array}$ & $\begin{array}{l}\text { Spline } \\
\text { poly } 3^{r d}\end{array}$ & $\begin{array}{c}\text { Spline } \\
\text { poly } 4^{t h}\end{array}$ \\
\hline North-West & $\begin{array}{c}0.012 \\
(0.109)\end{array}$ & $\begin{array}{c}0.057 \\
(0.088)\end{array}$ & $\begin{array}{c}0.043 \\
(0.122)\end{array}$ & $\begin{array}{c}0.167 \\
(0.152)\end{array}$ \\
\hline North-East & $\begin{array}{c}0.072 \\
(0.088)\end{array}$ & $\begin{array}{c}0.039 \\
(0.071)\end{array}$ & $\begin{array}{c}0.042 \\
(0.095)\end{array}$ & $\begin{array}{l}-0.039 \\
(0.115)\end{array}$ \\
\hline Center & $\begin{array}{l}-0.043 \\
(0.096)\end{array}$ & $\begin{array}{c}-0.032 \\
(0.079)\end{array}$ & $\begin{array}{l}-0.071 \\
(0.106)\end{array}$ & $\begin{array}{l}-0.181 \\
(0.133)\end{array}$ \\
\hline South & $\begin{array}{l}-0.041 \\
(0.075)\end{array}$ & $\begin{array}{c}-0.064 \\
(0.064)\end{array}$ & $\begin{array}{l}-0.013 \\
(0.088)\end{array}$ & $\begin{array}{c}0.053 \\
(0.110)\end{array}$ \\
\hline Area size & $\begin{array}{l}-2.791 \\
(9.045)\end{array}$ & $\begin{array}{c}-0.519 \\
(7.377)\end{array}$ & $\begin{array}{c}0.043 \\
(10.199)\end{array}$ & $\begin{array}{c}-7.710 \\
(11.734)\end{array}$ \\
\hline Sea level & $\begin{array}{l}-10.800 \\
(44.481)\end{array}$ & $\begin{array}{c}-9.053 \\
(34.398)\end{array}$ & $\begin{array}{l}-17.736 \\
(46.537)\end{array}$ & $\begin{array}{c}9.258 \\
(59.757)\end{array}$ \\
\hline Obs. & 2,080 & 3,068 & 6,300 & 6,300 \\
\hline
\end{tabular}

Notes. Municipalities between 3,500 and 7,000 inhabitants. Diff-in-disc estimates with changing population levels (1991 Census before 2001 and 2001 Census after 2001). All time-invariant characteristics are dummies except area size (in $\left.\mathrm{km}^{2}\right)$ and sea level (in meters). Estimation methods: Local Linear Regression (LLR) with bandwidth $h=500$ or $h=750$; spline polynomial approximation with $3^{r d}$-order or $4^{\text {th }}$-order polynomial. Robust standard errors clustered at the municipality level are in parentheses. Significance at the $10 \%$ level is represented by *, at the $5 \%$ level by **, and at the $1 \%$ level by $* * *$. 
Table A4: Balance tests of potentially endogenous characteristics

\begin{tabular}{|c|c|c|c|c|}
\hline & $\begin{array}{c}\text { LLR } \\
h=500\end{array}$ & $\begin{array}{c}\text { LLR } \\
h=750\end{array}$ & $\begin{array}{l}\text { Spline } \\
\text { poly } 3^{r d}\end{array}$ & $\begin{array}{l}\text { Spline } \\
\text { poly } 4^{t h}\end{array}$ \\
\hline Taxable income & $\begin{array}{c}211.702 \\
(638.019)\end{array}$ & $\begin{array}{c}-187.577 \\
(491.318)\end{array}$ & $\begin{array}{c}-230.188 \\
(679.745)\end{array}$ & $\begin{array}{c}-19.672 \\
(857.344)\end{array}$ \\
\hline Female mayor & $\begin{array}{l}-0.078 \\
(0.072)\end{array}$ & $\begin{array}{l}-0.083 \\
(0.064)\end{array}$ & $\begin{array}{l}-0.112 \\
(0.079)\end{array}$ & $\begin{array}{l}-0.068 \\
(0.095)\end{array}$ \\
\hline Mayor's age & $\begin{array}{c}0.457 \\
(2.846)\end{array}$ & $\begin{array}{l}-1.361 \\
(2.166)\end{array}$ & $\begin{array}{l}-0.770 \\
(3.114)\end{array}$ & $\begin{array}{l}-0.907 \\
(3.930)\end{array}$ \\
\hline Mayor's schooling & $\begin{array}{c}0.646 \\
(0.838)\end{array}$ & $\begin{array}{c}0.698 \\
(0.645)\end{array}$ & $\begin{array}{c}0.818 \\
(0.929)\end{array}$ & $\begin{array}{c}1.192 \\
(1.155)\end{array}$ \\
\hline Mayor's tenure & $\begin{array}{c}0.551 \\
(1.378)\end{array}$ & $\begin{array}{c}-0.081 \\
(1.110)\end{array}$ & $\begin{array}{c}0.444 \\
(1.497)\end{array}$ & $\begin{array}{c}1.287 \\
(1.848)\end{array}$ \\
\hline No. of parties & $\begin{array}{l}-0.394 \\
(0.440)\end{array}$ & $\begin{array}{l}-0.200 \\
(0.346)\end{array}$ & $\begin{array}{l}-0.498 \\
(0.485)\end{array}$ & $\begin{array}{l}-0.958 \\
(0.621)\end{array}$ \\
\hline Term limit & $\begin{array}{l}-0.097 \\
(0.136)\end{array}$ & $\begin{array}{l}-0.075 \\
(0.107)\end{array}$ & $\begin{array}{l}-0.136 \\
(0.150)\end{array}$ & $\begin{array}{l}-0.123 \\
(0.184)\end{array}$ \\
\hline Young cohorts & $\begin{array}{l}-0.085 \\
(0.141)\end{array}$ & $\begin{array}{l}-0.083 \\
(0.110)\end{array}$ & $\begin{array}{l}-0.065 \\
(0.154)\end{array}$ & $\begin{array}{l}-0.083 \\
(0.198)\end{array}$ \\
\hline Efficiency & $\begin{array}{c}0.052 \\
(0.152)\end{array}$ & $\begin{array}{c}0.044 \\
(0.116)\end{array}$ & $\begin{array}{l}-0.019 \\
(0.165)\end{array}$ & $\begin{array}{c}0.035 \\
(0.209)\end{array}$ \\
\hline Obs. & 2,080 & 3,068 & 6,300 & 6,300 \\
\hline
\end{tabular}


Table A5: The political economy of deficit bias, part I - Falsification test

\begin{tabular}{|c|c|c|c|c|}
\hline & $\begin{array}{c}\text { LLR } \\
h=500\end{array}$ & $\begin{array}{c}\text { LLR } \\
h=750\end{array}$ & $\begin{array}{c}\text { Spline } \\
\text { poly } 3^{r d}\end{array}$ & $\begin{array}{l}\text { Spline } \\
\text { poly } 4^{\text {th }}\end{array}$ \\
\hline & \multicolumn{4}{|c|}{ With two parties or less: } \\
\hline Deficit & $\begin{array}{c}4.342 \\
(8.885)\end{array}$ & $\begin{array}{l}-11.267 \\
(10.361)\end{array}$ & $\begin{array}{l}-2.061 \\
(11.445)\end{array}$ & $\begin{array}{c}2.368 \\
(12.799)\end{array}$ \\
\hline Obs. & 680 & 988 & 2,217 & 2,217 \\
\hline & \multicolumn{4}{|c|}{ With more than two parties: } \\
\hline Deficit & $\begin{array}{c}-2.905 \\
(11.359)\end{array}$ & $\begin{array}{c}-0.567 \\
(10.595)\end{array}$ & $\begin{array}{l}-1.459 \\
(13.363)\end{array}$ & $\begin{array}{l}-9.829 \\
(15.094)\end{array}$ \\
\hline Obs. & 580 & 864 & 1,963 & 1,963 \\
\hline $\begin{array}{l}\text { Difference between } \\
\text { the two subsamples }\end{array}$ & -7.247 & 10.700 & 0.602 & -12.197 \\
\hline $\begin{array}{l}\text { Wald test p-value } \\
\text { without covariates }\end{array}$ & 0.185 & 0.393 & 0.168 & 0.144 \\
\hline & \multicolumn{4}{|c|}{ With binding term limit: } \\
\hline Deficit & $\begin{array}{c}-4.222 \\
(14.889)\end{array}$ & $\begin{array}{c}0.764 \\
(13.381)\end{array}$ & $\begin{array}{c}2.291 \\
(17.202)\end{array}$ & $\begin{array}{l}-24.228 \\
(22.308)\end{array}$ \\
\hline Obs. & 388 & 550 & 1,213 & 1,213 \\
\hline & \multicolumn{4}{|c|}{ Without binding term limit: } \\
\hline Deficit & $\begin{array}{c}-2.862 \\
(11.869)\end{array}$ & $\begin{array}{c}-9.567 \\
(10.969)\end{array}$ & $\begin{array}{c}-4.463 \\
(13.794)\end{array}$ & $\begin{array}{c}4.983 \\
(16.837)\end{array}$ \\
\hline Obs. & 872 & 1,302 & 2,967 & 2,967 \\
\hline $\begin{array}{l}\text { Difference between } \\
\text { the two subsamples }\end{array}$ & 1.360 & -10.331 & -6.754 & 29.211 \\
\hline $\begin{array}{l}\text { Wald test p-value } \\
\text { without covariates }\end{array}$ & 0.945 & 0.559 & 0.762 & 0.303 \\
\hline
\end{tabular}

Notes. Municipalities between 3,500 and 7,000 inhabitants; budget years between 1997 and 2001. Diff-in-disc estimates of the impact of the false relaxation of fiscal discipline below 5,000 after 1999 in different subsamples (that is, above vs. below median number of parties; binding vs. non-binding term limit). Estimation methods: Local Linear Regression (LLR) with bandwidth $h=500$ or $h=750$, as in equation (4); spline polynomial approximation with $3^{r d}$-order or $4^{\text {th }}$-order polynomial, as in equation (5). The Wald test p-value without covariates evaluates whether the estimates are statistically different in the two subsamples. The Wald test p-value with covariates is not available because of data limitations before 1999. All variables are per capita and in 2009 Euros. Robust standard errors clustered at the municipality level are in parentheses. Significance at the $10 \%$ level is represented by *, at the $5 \%$ level by **, and at the $1 \%$ level by ***. 
Table A6: The political economy of deficit bias, part II - Falsification test

\begin{tabular}{|c|c|c|c|c|}
\hline & $\begin{array}{c}\text { LLR } \\
h=500\end{array}$ & $\begin{array}{c}\text { LLR } \\
h=750\end{array}$ & $\begin{array}{c}\text { Spline } \\
\text { poly } 3^{\text {rd }}\end{array}$ & $\begin{array}{c}\text { Spline } \\
\text { poly } 4^{t h}\end{array}$ \\
\hline & \multicolumn{4}{|c|}{ Young cohorts above median: } \\
\hline Deficit & $\begin{array}{c}4.124 \\
(9.125)\end{array}$ & $\begin{array}{l}-6.322 \\
(9.933)\end{array}$ & $\begin{array}{c}0.741 \\
(11.431)\end{array}$ & $\begin{array}{c}2.273 \\
(12.944)\end{array}$ \\
\hline Obs. & 805 & 1,160 & 2,599 & 2,599 \\
\hline & \multicolumn{4}{|c|}{ Young cohorts below median: } \\
\hline Deficit & $\begin{array}{c}2.581 \\
(15.266)\end{array}$ & $\begin{array}{c}-0.816 \\
(12.143)\end{array}$ & $\begin{array}{c}3.824 \\
(16.911)\end{array}$ & $\begin{array}{c}-1.688 \\
(21.845)\end{array}$ \\
\hline Obs. & 455 & 692 & 1,581 & 1,581 \\
\hline $\begin{array}{l}\text { Difference between } \\
\text { the two subsamples }\end{array}$ & -1.543 & 5.506 & 3.083 & -3.961 \\
\hline $\begin{array}{l}\text { Wald test p-value } \\
\text { without covariates }\end{array}$ & 0.933 & 0.733 & 0.885 & 0.882 \\
\hline
\end{tabular}

Notes. Municipalities between 3,500 and 7,000 inhabitants; budget years between 1997 and 2001. Diff-in-disc estimates of the impact of the false relaxation of fiscal discipline below 5,000 after 1999 in different subsamples (that is, above vs. below median percentage of young cohorts). Estimation methods: Local Linear Regression (LLR) with bandwidth $h=500$ or $h=750$, as in equation (4); spline polynomial approximation with $3^{r d}$-order or $4^{t h}$-order polynomial, as in equation (5). The Wald test p-value without covariates evaluates whether the estimates are statistically different in the two subsamples. The Wald test p-value with covariates is not available because of data limitations before 1999 . All variables are per capita and in 2009 Euros. Robust standard errors clustered at the municipality level are in parentheses. Significance at the $10 \%$ level is represented by ${ }^{*}$, at the $5 \%$ level by **, and at the $1 \%$ level by ***. 
Table A7: Fiscal restraints and budget management - Falsification test

\begin{tabular}{|c|c|c|c|c|}
\hline & $\begin{array}{c}\text { LLR } \\
h=500\end{array}$ & $\begin{array}{c}\text { LLR } \\
h=750\end{array}$ & $\begin{array}{c}\text { Spline } \\
\text { poly } 3^{r d}\end{array}$ & $\begin{array}{l}\text { Spline } \\
\text { poly } 4^{t h}\end{array}$ \\
\hline & \multicolumn{4}{|c|}{ Speed of public good provision above median: } \\
\hline \multirow[t]{2}{*}{ Deficit } & 2.989 & -2.653 & 6.135 & 0.430 \\
\hline & $(9.812)$ & $(8.166)$ & $(10.751)$ & $(13.740)$ \\
\hline \multirow[t]{2}{*}{ Obs. } & 652 & 977 & 2,283 & 2,283 \\
\hline & \multicolumn{4}{|c|}{ Speed of public good provision below median: } \\
\hline \multirow[t]{2}{*}{ Deficit } & 0.842 & -10.780 & -9.531 & -3.501 \\
\hline & $(11.906)$ & $(14.003)$ & $(15.465)$ & $(15.622)$ \\
\hline Obs. & 608 & 875 & 1,897 & 1,897 \\
\hline \multicolumn{5}{|l|}{ Difference between } \\
\hline the two subsamples & -2.147 & -8.127 & -15.666 & -3.931 \\
\hline $\begin{array}{l}\text { Wald test p-value } \\
\text { without covariates }\end{array}$ & 0.883 & 0.607 & 0.381 & 0.840 \\
\hline
\end{tabular}

Notes. Municipalities between 3,500 and 7,000 inhabitants; between 1997 and 2001. Diff-in-disc estimates of the impact of the false relaxation of fiscal discipline below 5,000 after 1999 in different subsamples (that is, above vs. below median speed of public good provision). Estimation methods: Local Linear Regression (LLR) with bandwidth $h=500$ or $h=750$, as in equation (4); spline polynomial approximation with $3^{\text {rd }}$-order or $4^{\text {th }}$-order polynomial, as in equation (5). The Wald test $p$-value without covariates evaluates whether the estimates are statistically different in the two subsamples. The Wald test p-value with covariates is not available because of data limitations before 1999. All variables are per capita and in 2009 Euros. Robust standard errors clustered at the municipality level are in parentheses. Significance at the $10 \%$ level is represented by ${ }^{*}$, at the $5 \%$ level by **, and at the $1 \%$ level by ***. 


\section{Figure A1: Density tests}

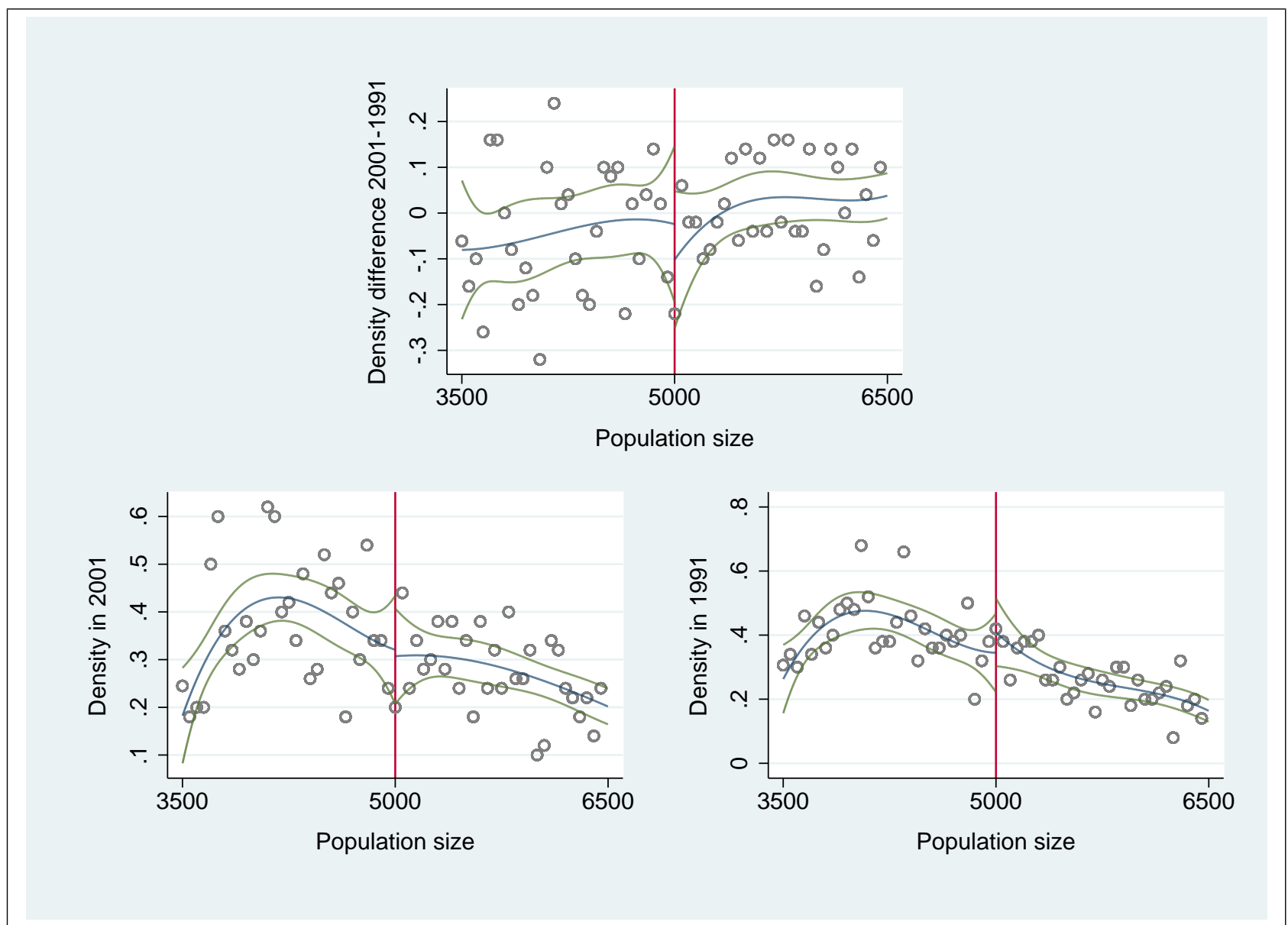

Notes. Test of the continuity at 5,000 of: (i) the difference between the density in the 2001 Census and in the 1991 Census (top graph); (ii) the density in the 2001 Census (bottom left graph); and (iii) the density in the 1991 Census (bottom right graph). The central line is a spline $3^{r d}$-order polynomial fit in population size; the lateral lines represent the $95 \%$ confidence interval. Scatter points are averaged over intervals of 50 inhabitants. 


\section{Figure A2: Placebo tests for deficit}

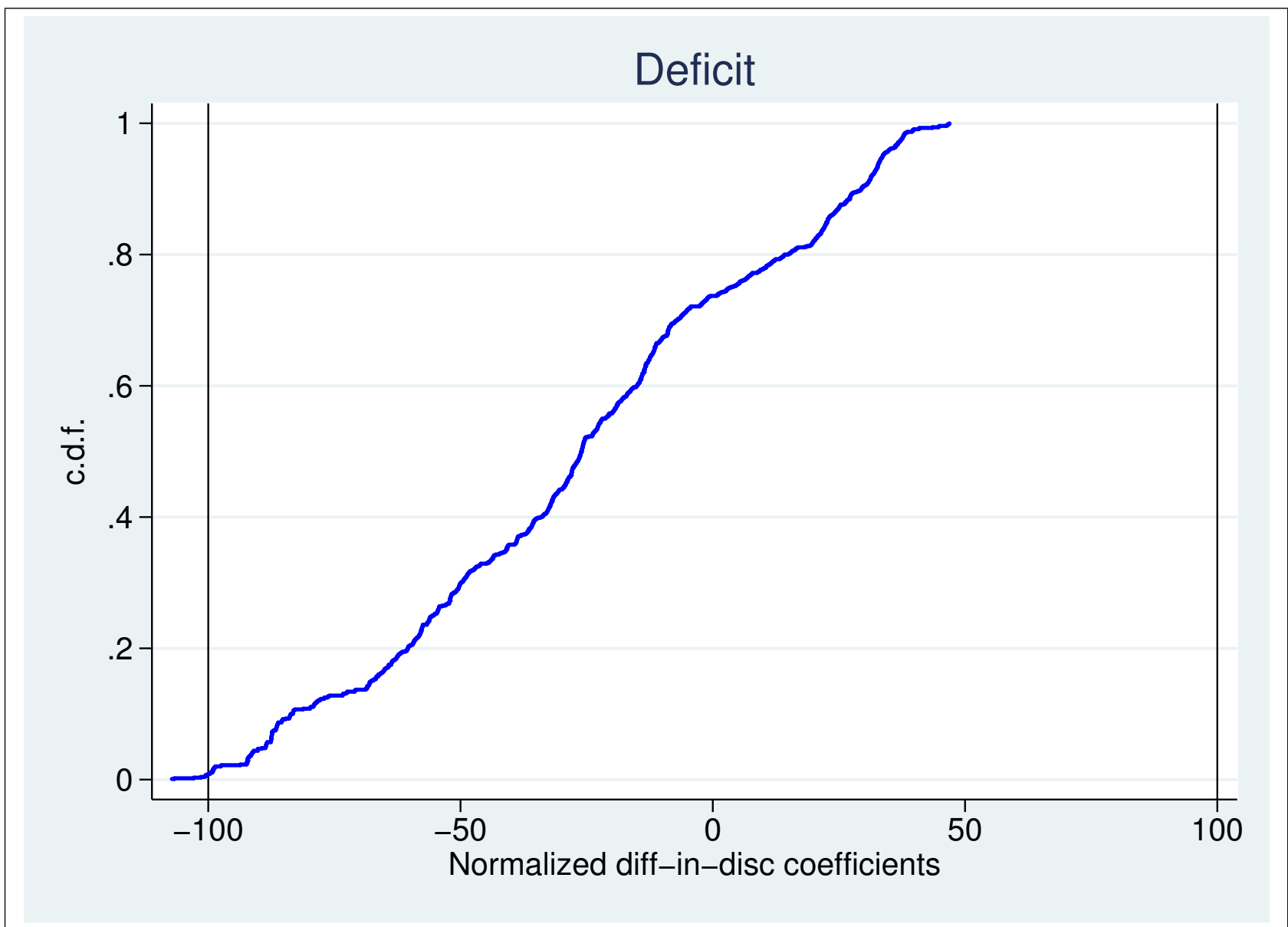

Notes. Placebo tests based on permutation methods for deficit. The figure reports the empirical c.d.f. of the normalized point estimates from a set of diff-in-disc estimations at 500 false thresholds below and 500 false thresholds above the true threshold at 5,000 (namely, any point from 4,900 to 4,400 and any point from 5,100 to 5,600). Estimation method: spline polynomial approximation with $3^{\text {rd }}$-order polynomial. The vertical lines indicate our benchmark estimate for deficit from Table 4 (i.e., true coefficient normalized to 100) and its negative value. 


\section{Figure A3: Placebo tests for fiscal gap}

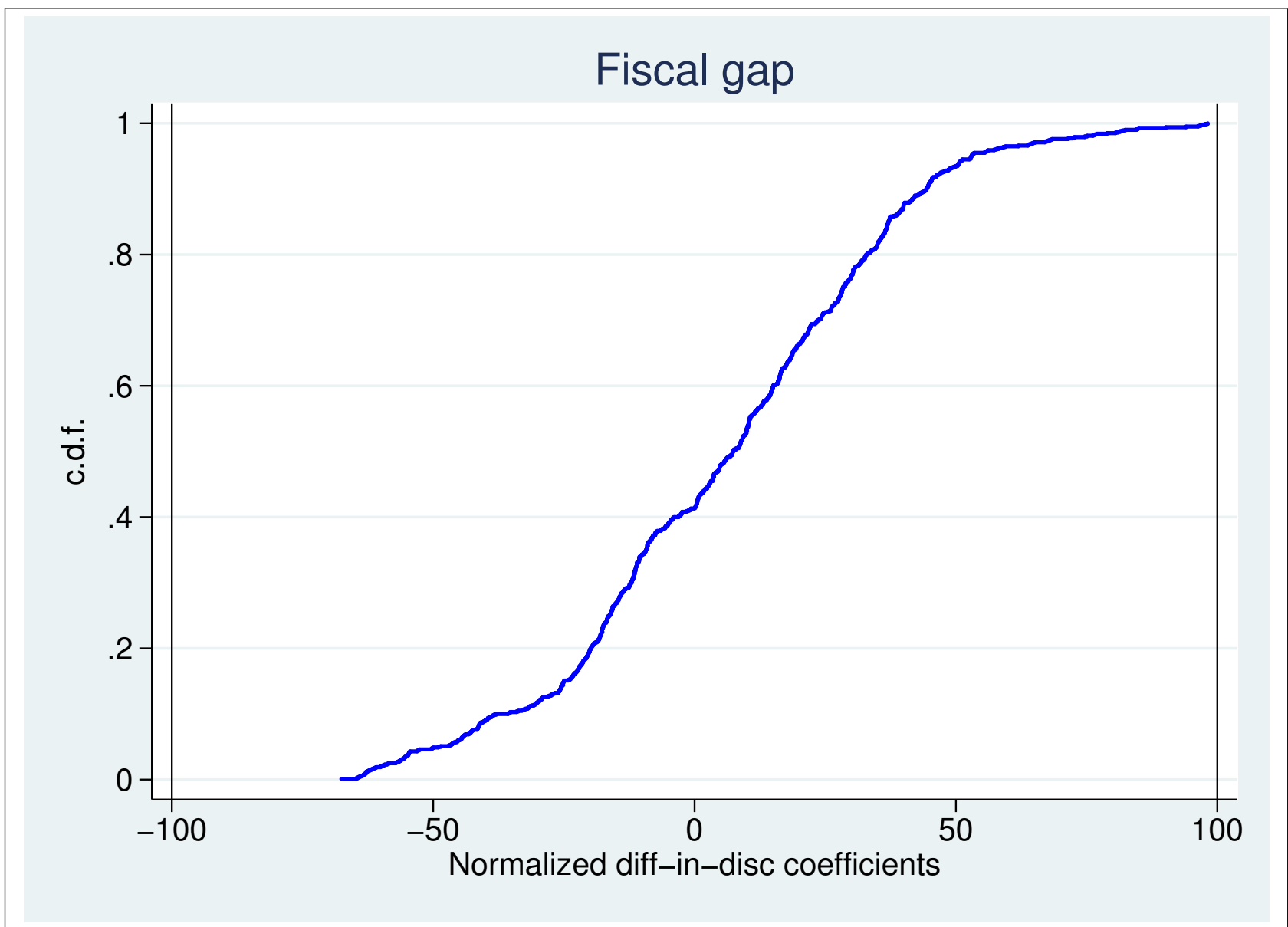

Notes. Placebo tests based on permutation methods for fiscal gap. The figure reports the empirical c.d.f. of the normalized point estimates from a set of diff-in-disc estimations at 500 false thresholds below and 500 false thresholds above the true threshold at 5,000 (namely, any point from 4,900 to 4,400 and any point from 5,100 to 5,600). Estimation method: spline polynomial approximation with $3^{r d}$-order polynomial. The vertical lines indicate the normalized benchmark estimate for fiscal gap from Table 4 (i.e., true coefficient normalized to 100) and its negative value. 